\title{
IMPORTÂNCIA DO CÁLCIO E DO EXERCÍCIO NA PREVENÇÃO DO ENCURVAMENTO DAS PERNAS EM FILHOTES DE EMA (Rhea americana, Linnaeus, 1758) EM CATIVEIRO
}

\section{MARISA ELISABET SANCHEZ \\ Prof. Ciencias Naturales}

Orientador: Prof. Dr. ABEL LAVORENTI

Dissertação apresentada à Escola Superior de Agricultura "Luiz de Queiroz", da Universidade de São Paulo, para obtenção do Título de Mestre em Agronomia - Área de Concentração: Ciência Animal e Pastagens.

PIRACICABA

Estado de São Paulo - Brasil

Dezembro - 1996 


\section{Dados Internacionais de Catalogação na Publicação (CIP) DIVISÃo DE BIBLIOTECA E DOCUMENTAÇÃo - Campus "Luiz de Queiroz"/USP}

\section{Sanchez, Marisa Elisabet}

Importância do cálcio e do exercício na prevenção do encurvamento das pernas em filhotes de ema (Rhea americana, Linnaneus, 1758) em cativeiro / Marisa Elisabet Sanchez. - Piracicaba, 1996.

71p. : il.

Dissertação (mestrado) - Escola Superior de Agricultura Luiz de Queiroz, 1996.

Bibliografia.

1. Cálcio para ema em cativeiro 2. Ema em cativeiro - Nutrição 3. Ema em cativeiro - perna - Distúrbio l. Título 


\section{IMPORTÂNCIA DO CÁLCIO E DO EXERCÍCIO NA PREVENÇÃO DO ENCURVAMENTO DAS PERNAS EM FILHOTES DE EMA (Rhea americana, Linnaeus, 1758) EM CATIVEIRO}

\section{MARISA ELISABET SANCHEZ}

Aprovada em: 13-12-96

Comissão Julgadora:

Prof. Abel Lavorenti

ESALQ/USP

Prof. Roberto Dias de Moraes e Silva ESALQ/USP

Prof ${ }^{a}$ Miriam Luz Giannoni UNESP

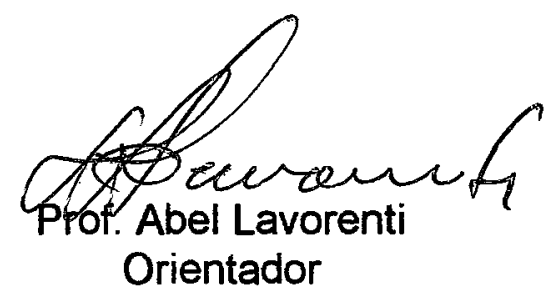


Ofereço,

a todas as"emas que perderam

sua liberdade e vida

neste trabalho"

dedico a meu

avô "Manuel". 
Agradeço à minha família, professores, instituições, funcionários e amigos, que direta ou indiretamente aconselharam, guiaram e auxiliaram na realização deste trabalho, especialmente aos que seguem:

- minha mãe Marta, Artur, flia. Costa, flia. Bastos, flia. Borges, flia. Elias,

- Prof. Abel Lavorenti, Prof. Roberto Dias de Moraes e Silva, Prof Miriam Luz Giannoni, Prof. Raúl D' Arce, Prof. Irineu Umberto Packer,

- Fundação Coordenação de Aperfeiçoamento de Pessoal de Nível Superior de São Paulo (CAPES), Fundação de Amparo à Pesquisa do Estado de São Paulo (FAPESP), Instituto Brasileiro do Meio Ambiente e dos Recursos Naturais Renováveis (IBAMA) do Estado de São Paulo, Parque Ecológico de São Carlos-SP, Supre-Mais Produtos Bioquímicos Ltda. de Valinhos-SP, Seção de Ciência dos Animais e de Química Analítica do Centro de Energia Nuclear na Agricultura (CENA) de Piracicaba-SP, Departamento de Patologia Veterinária da Universidade Estatual Paulista (UNESP) - Câmpus de Jaboticabal-SP, Clínica Veterinária Frasson Ltda. de Piracicaba-SP,

- aos funcionários do Departamento de Zootecnia do Setor Não Ruminantes da Escola Superior de Agricultura "Luiz de Queiroz", da Universidade de São Paulo (ESALQ/USP),

- Sr. Moacir Carvalho Dias, sítio Ferradura - Poços de Caldas-MG,

- Helder, Márcia, Paulo, Pilar, Alessandra, João Geraldo, Luciana, Luís Fernando, Cristian, Valéria. 


\section{SUMÁRIO}

Página

SUMÁRIO iii

LISTA DE FIGURAS .. $\mathrm{V}$

LISTA DE TABELAS ..............................................................................

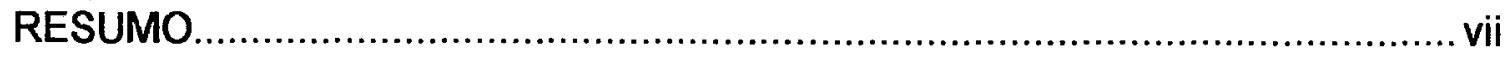

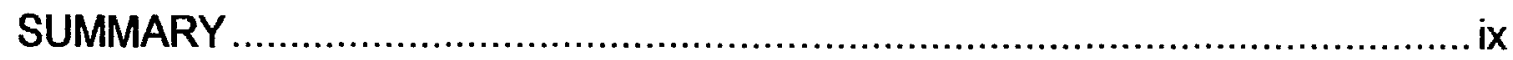

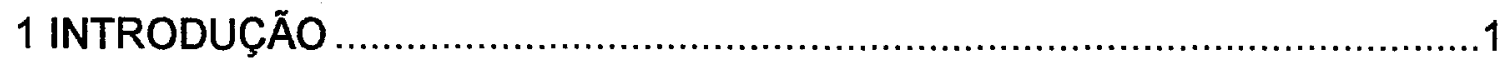

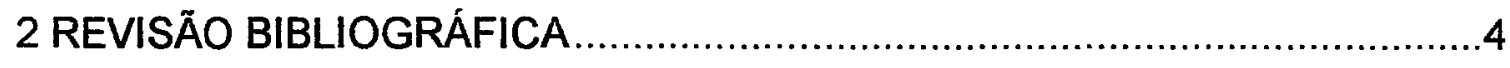

2.1 Origem, classificação zoológica e distribuição da espécie ..........................4

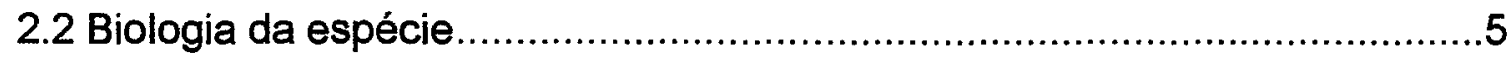

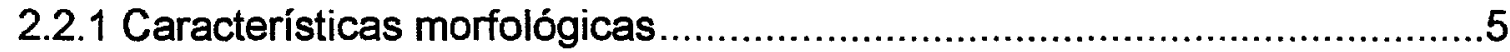

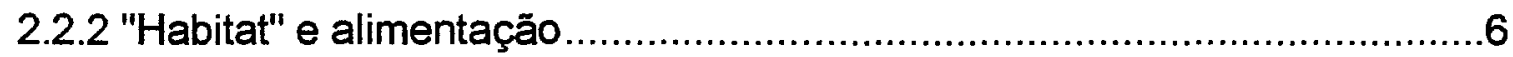

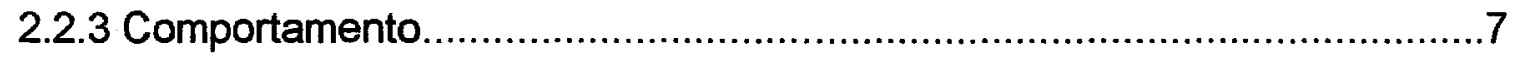

2.3 Aspectos gerais na exploração das Ratitas ...........................................10

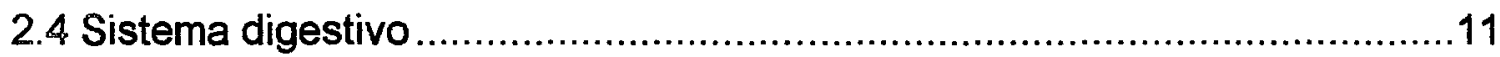

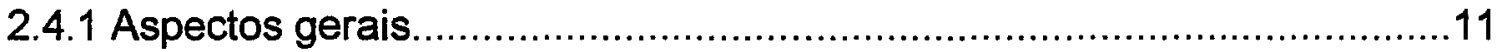

2.4.2 Anatomia e fisiologia digestiva das Ratitas.......................................12

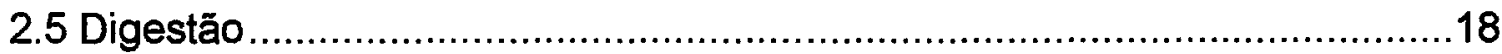

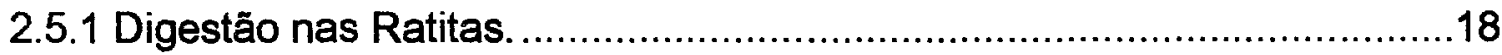

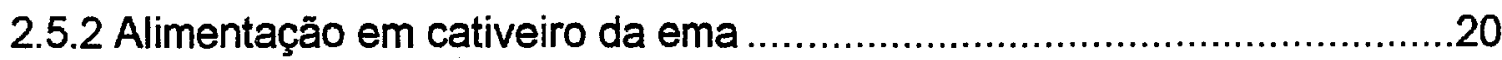

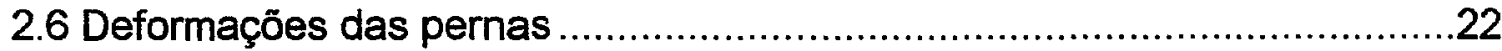

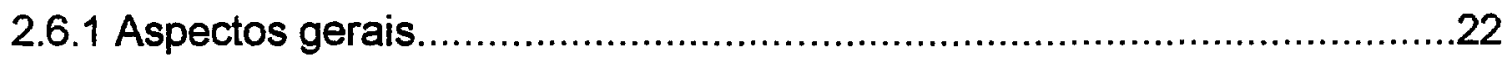

2.6.2 A importância da nutrição e do exercício nas deformidades nas

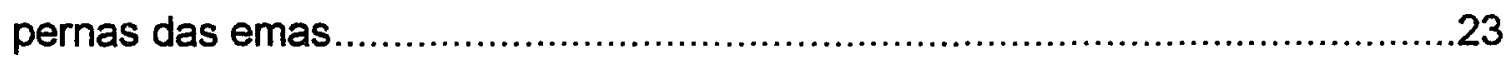

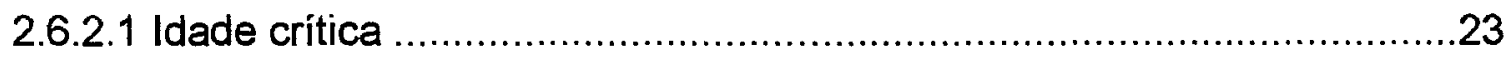




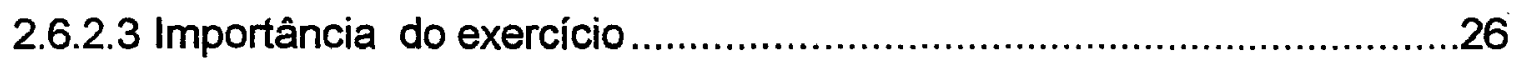

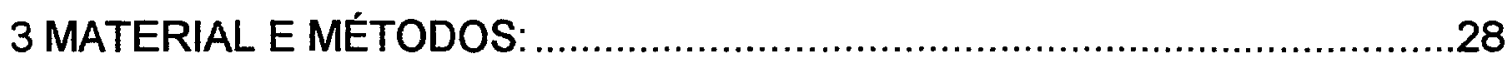

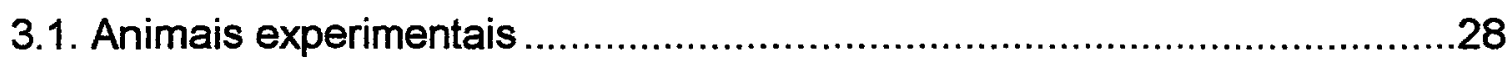

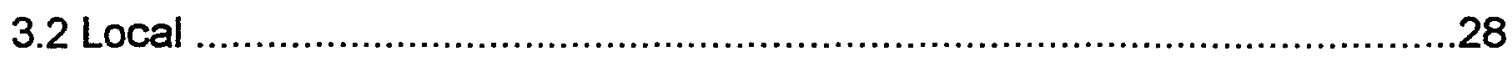

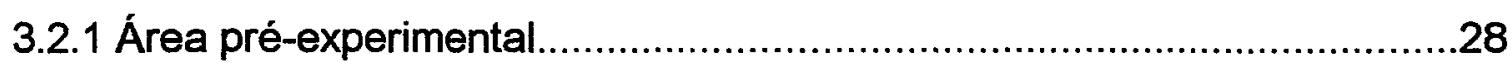

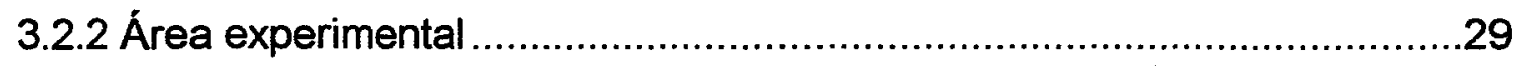

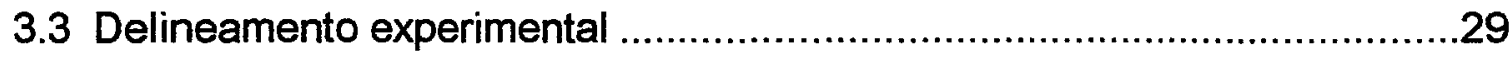

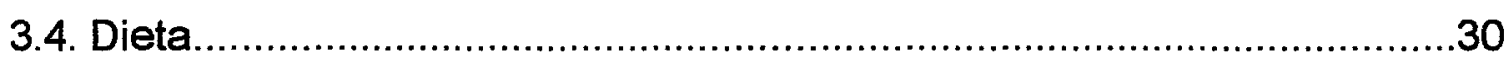

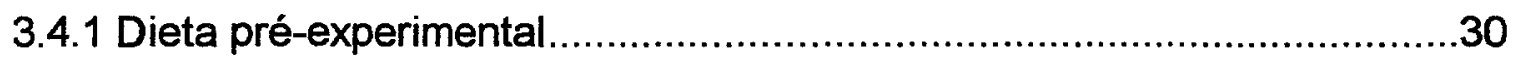

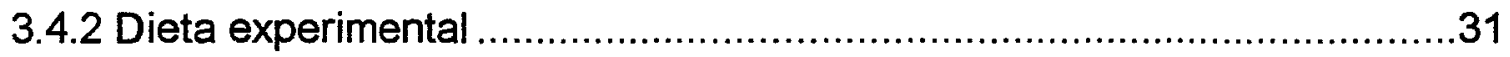

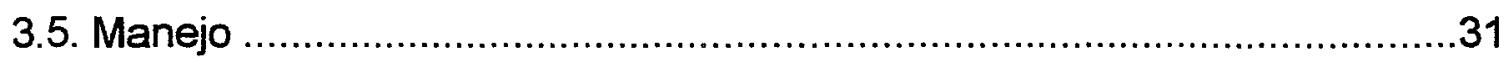

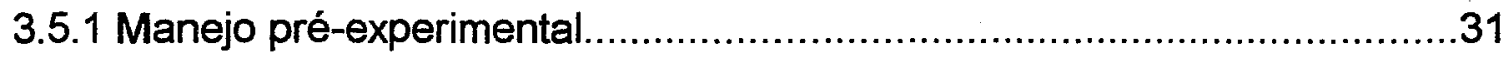

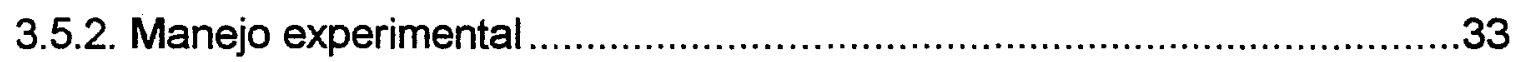

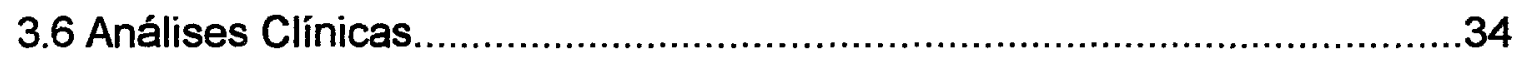

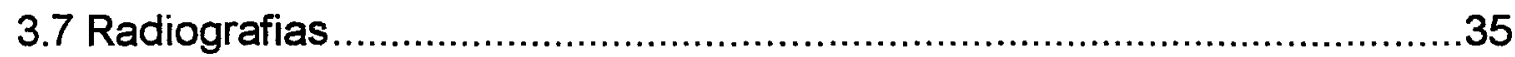

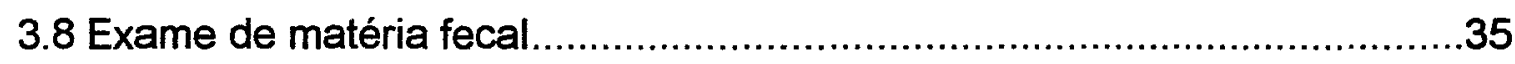

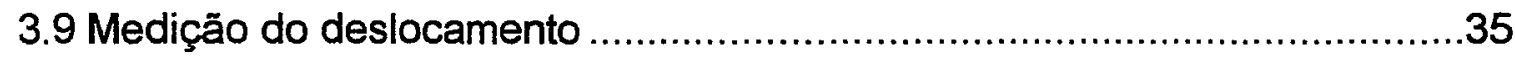

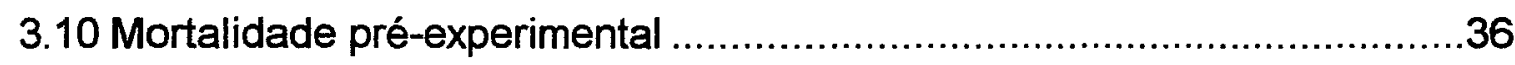

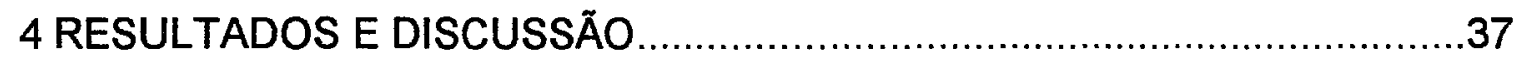

4.1 Medições do deslocamento das emas. ................................................45

4.2 Efeito das dietas nos parâmetros avaliados .........................................47

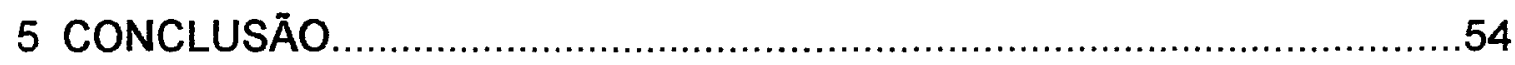

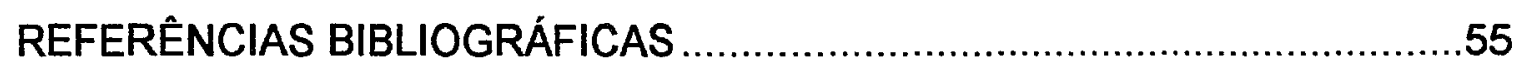

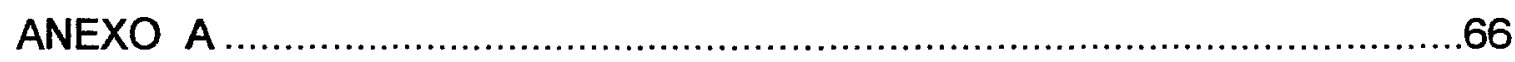

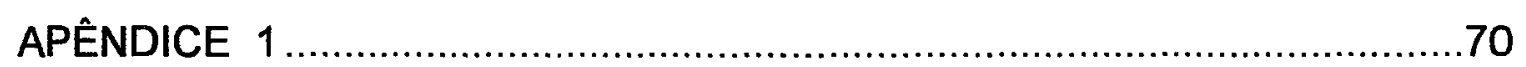




\section{LISTA DE FIGURAS}

Página

1 - Estomago de Ratitas. 1.- avestruz; 2- emú e casuarinos. G: área glandular do proventrículo. D: duodeno, E: esôfado. Pr. próventrículo. V: ventrículo. Fonte: Fowler (1991) ............................

2 - Curva duodenal secundária envolvendo o pâncreas no avestruz. Fonte: Co, et al. (1984).

3- Diferentes tendências das pautas comportamentais diárias dos filhotes de ema, (beb:bebendo; bic:bicando; bri:brigando; cam:caminhando; com:comendo; cor:correndo; dei:deitado; dor:dormindo; par:parado; sen:sentado; zig:ziguezague).

4- Gráfico de regressão linear do consumo semanal.

5. Gráfico de regressão linear do crescimento do tibiotarso..................... 50

6. Gráfico de regressão linear do crescimento do metatarso.

7. Gráfico de regressão linear, do crescimento proporcional dos ossos tibiotarso e metatarso.

8. Gráfico descritivo da variável ganho de peso semanal, em ambos tratamentos. 


\section{LISTA DE TABELAS}

Páginas

1. Comprimento relativo dos intestinos e cecos das Ratitas.

2. Tendências dos principais nutrientes (\%) requeridos pelas emas....

3. Quantidade de ingredientes utilizados na preparação dos dois tratamentos.

4. Composição bromatológica calculada dos dois tratamentos.

5. Valores médios e desvio padrão obtido para Hemoglobina e Hematócrito em sangue, para cada sexo e dieta, em filhotes com aproximadamente 90 dias.

6. Valores de fósforo obtidos no plasma de filhotes de ema com aproximadamente 90 dias.

7. Resultados obtidos ao exame histopatológico dos 13 óbitos ocorridos por septicemia nos filhotes de ema.

8. Valores de cálcio no osso, de fósforo no osso e no músculo nos filhotes de ema, no período pré-experimental (ração contendo $\begin{array}{llllll}\text { cálcio } \quad(\operatorname{máx}) & 1,50 \% & \mathrm{e} & \text { fósforo } & \text { (min) }\end{array}$ $0,50 \%)$

9. Valores de selênio no fígado nos filhotes de ema, no período préexperimental.

10. Análise descritiva dos valores médios, dos parâmetros estimados semanalmente, peso, consumo, comprimento do bico, tibiotarso e metatarso, para os tratamentos.

11. Coeficientes de correlação entre as variáveis para o Tratamento 1.

13. Coeficientes de correlação entre as variáveis para o Tratamento $2 \ldots$ 


\title{
IMPORTÂNCIA DO CÁLCIO E DO EXERCICIO NA PREVENÇÃO DO ENCURVAMENTO DAS PERNAS EM FILHOTES DE EMA (Rhea americana, Linnaeus, 1758) EM CATIVEIRO
}

\author{
Autora: Marisa Elisabet Sanchez \\ Orientador: Prof.Dr. Abel Lavorenti
}

\section{RESUMO}

Existe atualmente um grande interesse na manutenção da ema (Rhea americana, Linnaeus, 1758) em cativeiro com o objetivo de explorá-la economicamente. A convenção sobre Comércio Internacional de Espécies Ameaçadas de Fauna e Flora (CITES) a inclui em seu Apêndice II, já que atualmente, as populações desta espécie têm diminuído pela sua exploração irracional.

A incidência de desordens no sistema locomotor nestas aves poderia ser a principal causa de mortalidade na criação intensiva, sendo o período crítico entre 0 a 3 meses de idade. As principais causas para estas deficiências são de três tipos: nutricionais, falta de exercício e genéticas. A classificação das desordens do esqueleto é difícil e quase sempre arbitrária, especialmente com sua etiologia. Nas Ratitas estas deficiências são descritas normalmente como deformidades das pernas.

O osso é um tecido muito complexo que está intimamente relacionado com o crescimento em geral. Vários nutrientes afetam o crescimento, desenvolvimento e manutenção óssea das aves. $O$ cálcio cumpre uma função 
vital para a formação dos ossos nas aves e a deficiência deste mineral pode provocar anormalidades ósseas, dificultando a criação das aves em cativeiro.

O exercício seria outro fator predisponente ao entortamento das pernas, considerando-se que na natureza, a ema anda interruptamente, vários quilômetros por dia a procura de alimento.

O objetivo deste trabalho foi testar diferentes níveis de cálcio $(1,4 \%$ e $0,7 \%$ ) numa dieta balanceada segundo as exigências nutricionais das emas, na fase de crescimento, e analisar a capacidade de deslocamento dos animais no recinto, estabelecendo sua relação com o problema das pernas.

Semanalmente, durante o período experimental, foram avaliados o peso, consumo alimentar e foram medidos os parâmetros de crescimento: comprimento do bico, tibiotarso e metatarso.

Os filhotes de ema em crescimento ( de 30 a 90 dias de idade) não apresentaram encurvamento das pernas nos dois tratamentos. No entanto, observou-se diferenças significativas entre os tratamentos para outros parâmetros estudados. No tratamento dois obteve-se os melhores pesos e os melhores valores nos parâmetros de crescimento. Das atividades diárias, realizadas pelos filhotes, o caminhar e bicar 0 chão foram as pautas comportamentais que tomaram a maior parte do dia.

Foi possível concluir, que o melhor desempenho dos animais (peso, e medidas de crescimento) foram obtidos com o tratamento 2 com $1,4 \%$ de cálcio e com a relação Ca:P de $2: 1$. O exercício diário realizado pelos aves possivelmente, favoreceu o seu crescimento normal. 


\section{IMPORTANCE OF CALCIUM AND EXERCISE FOR THE PREVENTION OF BOW LEGS IN RHEA CHICKENS (Rhea americana, Linnaeus, 1758) IN CAPTIVITY.}

Author: Marisa Elisabet Sanchez Adviser: Prof. Dr. Abel Lavorenti

\section{SUMMARY}

At present there is great interest in keeping Rhea chickens ( Rhea americana, Linnaeus, 1758) in captivity for the purpose of commercial exploitation. They have been included in the CITES (Convention on International Trade in Endangered Species of Wild Fauna and Flora), Apendix II, since their population has decreased due to irrational exploitation.

The incidence of disorders in their locomotive system may be the main cause of mortality on farms, the period being between 0 and 3 months of age.

There are three principal causes of this deficiency : nutrition, lack of exercise and genetic factors. The classification of skeletal disorders is always controversial, especially as regards etiology. In the Rhea and Ratites in general, these diseases are normally described as leg malformation.

Bone is a very complex tissue, usually related to general growth. Several nutrients affect the growth, development and bone maintenance of growing birds. Calcium has a vital function in their bone formation of growing birds. Its deficiency causes bone abnormalities making it difficult to breed them in captivity. 
Exercise is considered to be a favorable factor to bow leg, taking into consideration that the rhea walks ininterruptedly, several kilometers a day seeking for food.

The main purpose of this experement has been to test the different levels of calcium $(1,4 \%$ and $0,7 \%)$ and examine the animals moving capacity in their enclosure in order to establish the relation with their leg problem.

Weight and food consumption were evaluated and growing parameters measured: length of beak, tibiotarsus and metatarsal.

Growing Rhea chicken ( 30 to 90 days of age) did not show bow leg on either of the diets, although important differences between them were observed in relation to the studied parameters. The best weight and growing parameters were obtained with the second diet. Among their daily activities, picking at the ground and walking about were those performed most of the time.

It was concluded that the best performance (weight and growing measurments) was obtained with the second diet, containing 1,4\% calcium and with a Ca:P ratio of $2: 1$ and daily exercise may have favored normal growth. 


\section{INTRODUÇÃO}

A ema (Rhea americana, Linnaeus, 1758) a maior ave sul-americana, é uma das espécies da ordem Rheiformes. Esta ordem, junto com os Struthioniformes (avestruzes da África), Casuariiformes (emus e casuares da Austrália e Nova Guiné) e Apterygiformes (kiwis da Nova Zelândia) são agrupados dentro do grupo das Ratitas (aves não voadoras) (Sherwood \& Parsons, 1985; Almazán et al., 1986). Este grupo teria evoluido a partir de um ancestral comum, presente há aproximadamente 100 milhões de anos no antigo continente do Gondwana e havia-se diversificado durante 0 isolamento geográfico, consequente do processo de fragmentação deste continente (Cracraft, 1974).

O grande interesse pela exploração das Ratitas iniciou-se na África em 1838 com a criação do avestruz, devido ao valor comercial de suas penas. A caça predatória levou a drástica reclução de populações naturais, e até a extinção de grupos genéticos como a sub-espécie Struthio camelus syriacus. As criações estabeleceram-se em outros países, buscando o desenvolvimento de uma pecuária alternativa, incluindo a Europa e os Estados Unidos (Jensen, 1989). A ema também foi sujeita, desde tempos remotos, a uma exploração irracional de seus produtos e subprodutos (couro, penas, carne, osso, etc.) resultando na di\$̣minuição das populações (Waller, 1991). A convenção sobre Comércio Internacional de Espécies Ameaçadas da Fauna e Flora Silvestre (CITES) inclui em seu Apêndice I ao gênero Pterocnemia e no Apêndice II ao gênero Rhea. 
Atualmente, a ema é criada em cativeiro na Europa, Índia, Canadá, Estados Unidos, Uruguaj e Brasil. A primeira tentativa no Brasil de criação de emas foi em 1937, realizada pelo Governo do Estado de São Paulo, no Parque de Água Funda, onde foi enfrentado o sério problema de fraturas nas pernas. A causa possível foi uma enfermidade óssea ou defeito genético (Nogueira-Neto, citado por Dani, 1993). Na criação da ema em cativeiro, uma das principais causas da mortalidade dos filhotes são as doenças nas pernas (Chapman \& Bass, 1994).

As anormalidades no sistema locomotor das aves têm sido problema desde o início de sua produção confinada, especialmente em frangos de corte. As anormalidades ósseas não são clinicamente visíveis, provocando quebras de ossos no manuseio e transporte, resultando em mortalidade nas granjas. 0 osso é um tecido muito complexo que está intimamente relacionado com o crescimento em geral (Tardin, 1995), sendo que o cálcio cumpre uma função vital para a formação dos ossos nas aves em crescimento ( Sigier, 1994).

Nas Ratitas, o encurvamento dos ossos tíbio-tarsal é considerado uma sindrome possivelmente multifatorial, que envolve características genéticas, práticas de exercício e o estado nutricional (Perelman citado por Jensen, et al., 1992). O fator nutricional tem sido comprometido, em particular, com a excessiva taxa de crescimento associada com deficiências na ração de cálcio elou fósforo, selênio e vitamina $E$, entre outros. A deficiência, principalmente do cálcio, pode provocar anormalidades ósseas (Wallach, 1970), dificultando a criação destas aves em cativeiro.

Os filhotes na natureza caminham vários quilômetros por dia a procura do alimento, e isto os ajuda a fortalecer os músculos das pernas. Bruning (1973) sugere que a falta de exercício seria o fator que predispõe o encurvamento das pernas. Jensen (1989) considera que o encurvamento das 
pernas nos filhotes seja atribuido à deficiências nutricionais e à falta de exercício.

O presente estudo tem por objetivo estudar as possiveis causas que poderiam provocar o entortamento das pernas de filhotes de ema em cativeiro, estabelecendo uma dieta segundo às exigências nutricionais dos filhotes, utilizando diferentes niveis de cálcio e analisando a capacidade de deslocamento dos animais no recinto, para estabelecer possível relação com o problema das pernas. Pretende-se contribuir para a solução deste problema melhorando as condições de criação da ema para sua exploração racional e conservação da espécie como patrimônio natural. 


\section{REVISÃO BIBLIOGRÁFICA}

\subsection{Origem, classificação zoológica e distribuição da espécie}

A ema, como o avestruz, casuar, kiwi e emu, pertencem a Classe Aves (únicos animais que apresentam penas), Subclasse Neornithes (todas as formas atuais), Superordem Paleognathas (aves corredoras incapazes de voar), Grupo Ratitas (cujo osso esterno carece de carena ou quilha, onde os músculos das asas estão fixados, impedindo o vôo) (Weichert, 1965).

As Ratitas são consideradas as aves atuais mais primitivas do ponto de vista filogenético (Sick, 1984) e seus ancestrais seriam, para alguns autores, aves voadoras (Sick, 1984; Sherwood \& Parsons, 1985; Fowler, 1991) e para outros, não voadoras (Andrade, 1993).

A ema pertence a Ordem Rheiforme

Familia Rheidae

Gênero Rhea (Brisson, 1760)

Espécie Rhea americana (Linnaeus, 1758)

Inskipp et al. (1988) dividiu a espécie Rhea americana em 5 subespécies, distribuidas todas no continente Sul-americano (Giannoni \& Sanchez, 1995): Rhea americana albescens ou rosthchildi, Arribalzaga e Holmberg, 1878; Rhea americana intermedia, Rothschield e Chubb, 1914; 
Khea americana americana, Linnaeus, 1758; Rhea americana nobilis Brodokorb, 1939; e Rhea americana araneipes, Brodokorb, 1938. As áreas de distribuição estão apresentada no Apêndice 1, Mapa1.

A familia Rheidae apresenta também o gênero Pterocnemia, conhecido como a ema de "Darwin", que é menor que a do gênero Rhea. Canevari et al. (1991) considera este gênero representado pela espécie Pterocnemia pennata, e as subespécies Pterocnemia pennata pennata, Orbigny, 1834 e Pterocnemia pennata garleppi, Chubb, 1913. As áreas de distribuição são apresentadas no Apêndice 1, Mapa 1.

\subsection{Biologia da espécie}

\subsubsection{Características morfológicas}

Morfologicamente a ema apresenta penas macias e cinzentas que se dirigem obliquamente de cima para baixo, formando um manto que se eleva em uma corcova dorsal e envolve todo o corpo, exceto o traseiro que é branco e coberto por curtas penas piliformes. $O$ baixo dorso e partes inferiores são esbranquiçados. A cabeça e o pescoço emplumados de cinza-pardacento, sendo que o macho distingue-se por ter a base do pescoço, peito anterior $e$ parte mediana do dorso anterior negros (Sick, 1984), no entanto, estas caracteristicas variam nas diferentes subespécies

Os tarsos são longos, robustos e carecem de penas, os pés estão constituídos por 3 dedos (diferenciando-se do avestruz que apresenta só 2 dedos) dirigidos para frente $e$ as unhas compridas lateralmente (Dabbene, citado por Dani, 1993). O bico é curto e plano, as narinas são largas, ovóides 
localizadas na região média do bico, em um sulco membranoso. A disposição dos olhos e a depressão posterior da órbita são tais, que permitem que a ave olhe para trás (Santos, 1990). As longas asas são de grande utilidade quando a ema é perseguida, correm executando ziguezagues (Daciuk, 1979), com as asas alternadamente abaixadas e levantadas, permitindo-the o equilibrio. $\mathrm{Na}$ corrida a ema pode atingir sessenta quilômetros por hora (Sick, 1984). Os machos chegam a medir 1,50 m de altura, atingindo $40 \mathrm{~kg}$ de peso vivo (Pv) e as fêmeas não excedem $1,30 \mathrm{~m}$ de altura e os 25-30 kg Pv (Almazán et al., 1986).

\subsection{2 "Habitat" e alimentação}

As emas são aves de hábitos diurnos, gregárias, que vivem em grupos de poucos individuos ou em bandos de até 40 individuos (Bruning, 1974). Habitam as regiões campestres, cerrados e arvoredos, de clima quente e temperado (Olalla \& Magalhães, 1956). São omnivoras (Daciuk, 1979) e as observaçōes feitas sobre o conteúdo gástrico desta ave revelam insetos e folhas de plantas (Moojen et al., 1941). A ausência quase total de paladar e o alto poder digestivo que possuem, Ihes permite digerir praticamente tudo o que comem (Gunski, 1992). Pastam devagar e procuram seu alimento que é muito variado. Alimenta-se de folhas espinhosas e ardidas, frutas, sementes, insetos, particularmente moscas, gafanhotos, invertebrados como minhocas, e pequenos vertebrados (Olalla \& Magalhães, 1956; Ruschi, 1979; Sick, 1984). As emas podem coexistir em companhia de vacas e ovelhas, sendo mínima a competição porque, na verdade, comem grande quantidade de espécies vegetais indesejáveis ( Almazán et al. 1986). 
A germinação e dispersão de sementes poderiam ser algumas das principais funções ecológicas desta espécie (Magnani \& Paschoal, 1990), além da limpeza dos campos e pastagens de plantas daninhas e pequenos animais invertebrados e vertebrados que poderiam-se transformar em praga (Ruschi, 1979; Dani, 1993).

\subsubsection{Comportamento}

As emas passam o dia em procura de seu alimento ininterruptamente (Olalla \& Magalhães, 1956). Durante o periodo de muito calor ofegam de bico meio aberto, refrescando-se e consumindo água ocasionalmente (Daciuk, 1979). A limpeza das penas é outra atividade que realizam algumas vezes ao dia. Descansam sentadas sobre os tarsos e às vezes entram em decúbito ventral, com as pernas estiradas para trás. Dormem com o pescoço esticado horizontalmente no chão ou dobrado para suas costas (Sick, 1984). No grupo existe uma hierarquia social com machos dominantes e entre estes as distâncias individuais são mantidas com pouca agressão (Dolensek \& Bruning, 1986).

As emas atingem a maturidade sexual aos dois anos de idade (Almazán et al., 1986) e o período de reprodução começa, normalmente, no início de julho, dependendo da latitude, a qual condiciona o fotoperíodo regional (El Ñandú, 1983), fragmentando-se nessa ocasiāo o grupo invernal. Três grupos são constituídos: 1)grupos formados por 1 ou 2 machos e várias fêmeas, 2) grupos de machos imaturos, e 3) grupos de machos jovens (Bruning, 1974). Os machos polígamos, do grupo reprodutor, mudam seu comportamento totalmente, tornando-se agressivos em procura de suas fêmeas (Muñiz, 1916). 
Durante o cortejo se inicia um comportamento de interações agonísticas, onde os machos enfrentam-se, golpeando seus peitos, bicando-se fortemente (Sick, 1984). O macho vencido é o primeiro a ir embora e o macho dominante continua cortejando seu harém (integrado por 2 a 5 fêmeas) constituindo um grupo potencialmente reprodutor (Daciuk, 1979). O macho estende suas asas horizontalmente, abaixando sua cabeça ao nível do corpo e lentamente caminha em direção a fêmea rodeando-a, numa atitude de exibição chamada "display" (Bruning, 1974). Esta exibição é intensificada e o "chamado das fêmeas" se inicia, emitindo um som de tom agudo e intenso que pode ser ouvido à distância, tendo uma conotação agonística (Raikow, 1969), até as fêmeas se mostrarem receptivas. $O$ ato da cópula tem uma duração aproximada de dois minutos (Brito, 1949) e a fêmea deita no chão e o macho efetua a monta apoiando-se sobre os calcanhares.

Os machos realizam a incubação e a criação dos filhotes e o papel da fêmea é limitado à copular e botar os ovos. O macho seleciona os possíveis locais onde construirá o ninho (Handford \& Mares, 1985). Após a escolha do local, prepara uma depressão, cavando o solo com seu pé (Raikow, 1969) e a seguir, com o bico, corta o capim ou qualquer folhagem ao redor do ninho, pisando a vegetação e puxando o material obtido para a escavação, o que resulta em uma área perfeitamente limpa de dois a três metros de raio (Sick, 1984). O macho conduz as fêmeas ao ninho para a postura.

A fêmea, durante a postura, se aproxima devagar na margem do ninho, se ajoelha em seu calcanhar perto do macho e deposita o ovo (Apêndice 1, Figura 2) se retira rapidamente, enquanto o macho rola o ovo com o bico e o coloca junto com os outros (Raikow, 1969). Cada fêmea é capaz de pôr de 10 a 18 ovos em um só período de postura (Sick, 1984), em intervalos de 48 horas e entre às 11:00 horas da manhã e às 15:00 horas da 
tarde (Handford \& Mares, 1985). Se nenhum macho estiver pronto com um ninho, simplesmente os ovos são jogados em outro lugar e estes ovos são chamados de guachos, ou ovos perdidos (Onelli, 1905; Wetmore, 1926). As fêmeas abandonam o macho assim que este inicia a incubação, para se reunir com outros machos, caracterizando o comportamento poliándrico (Brito, 1949).

A incubação é feita só pelo macho, com duração entre 36 e 38 dias (Bruning, 1971). O macho aceita novos ovos por um período de até 10 dias ao início da incubação (Vleck et al., citado por Dani, 1993).

Considera-se completa, uma postura de 20 a 30 ovos (Sick, 1984) sendo que já foram observadas ninhadas com mais de 30 (Olalla \& Magalhães, 1956; Ruschi, 1979). Cada ovo pesa de 500 a $600 \mathrm{~g}$ e apresenta forma oval alongada, superfície muito porosa e lisa, cor amarela, tornando-se branca durante a incubação (Olalla \& Magalhães, 1956; Ruschi, 1979). O macho altera freqüentemente a posição dos ovos no ninho, girando-os com seu bico, uma volta completa $\left(360^{\circ}\right)$ a cada vinte e quatro horas (Sick, 1984). O macho se alimenta fora do ninho entre as 11:00 e 16:00 horas (Bruning, 1974), olhando continuamente para todos os lados com o pescoço em posição vertical, controlando tudo ao redor.

Os próprios filhotes rompem a casca dos ovos, com o auxilio da formação córnea na extremidade de seu bico, eclodindo juntos no mesmo dia com apenas horas de diferença (Sick, 1984). O macho se retira do ninho após 36 horas, junto com os filhotes, que são capazes de correr e se alimentar sozinhos (Handford \& Mares, 1985). O macho fica com os filhotes, isolado do resto do grupo, atacando agressivamente a qualquer membro do grupo que se aproxime ou seus inimigos silvestres, principalmente os carcarás Polyborus plancus (Bruning, 1974). 
Os filhotes são muitos ativos, alimentando-se de insetos vigorosamente durante a primeira semana e, gradualmente, vão incorporando, na sua dieta, matéria vegetal (Bruning 1974), dispersam-se continuamente, e quando ficam longe do pai ou em perigo, emitem um "assobio" (chamado) e o pais os procuram (Raikow, 1969). É notável o crescimento dos filhotes e aos seis meses de idade se incorporam ao resto do grupo.

\subsection{Aspectos gerais na exploração das Ratitas}

A ema está sendo explorada comercialmente principalmente nos Estados Unidos e Canadá, onde o interesse pela exploração vêm evoluindo a cada ano e pesquisas estão sendo desenvolvidas com 0 apoio de Universidades e Associações (Giannoni, 1996). Na Argentina, pela resolução 24/86 da "Secretaria de Agronomia, Ganaderia y Pesca de la Nación" é proibido a comercialização da subespécie Rhea americana albescens. A Direção de Fauna Nación, autorizou um limite de exportação de couros por ano, para eliminar os excedentes que não puderam ser comercializados depois da proibição (Waller, 1991). No Uruguai, existe atualmente, a maior criação de emas de América do Sul, sendo esta a principal fornecedora de subprodutos para o mercado Europeu (Wolaj', 1996 ).

A exploração do avestruz, no entanto, vêm sendo feita na África do Sul há mais de 100 anos, pelo valor comercial de suas penas. As criações se estabeleceram em outros países em busca de uma pecuária alternativa, incluindo a Europa e os Estados Unidos (Jensen et al., 1992). Hoje os principais produtos são a carne, couro e penas. Os avestruzes produzem, em média, $40 \mathrm{~kg}$ de carne por ave, carne essa que tem aparência carne bovina e

\footnotetext{
${ }^{1}$ - Wolaj, R. 1996. Comunicação pessoal. Bat lana Rhea Farm - Don Elias S.G. Salto Uruguai.
} 
baixo índice de gordura (Figueiredo ${ }^{2}$, 1996). Atualmente no Brasil, o avestruz foi introduzido e explorado comercialmente nos estados de São Paulo e Goiás.

Os principais subprodutos da ema são: o couro, resistente e flexível, com aproximadamente 0,46 a $0,65 \mathrm{~m}^{2}$ de couro, 9 a $12 \mathrm{~kg}$ de carne vermelha, semelhante ao da carne bovina, com baixo teor de colesterol; as penas para confecção de fantasia e espanadores (Giannoni, 1996) e o óleo usado na indústria farmacêutica pelas propriedades anti-inflamatória, cicatrizante e hipoalergênica (Drenowatz, 1995; Fezler \& Beal, 1996). Evidentemente, ainda existe nestas aves um potencial genético latente a ser pesquisado.

\subsection{Sistema digestivo}

\subsubsection{Aspectos gerais}

Nas aves em geral, a anatomia do canal alimentar é notavelmente diferente.da dos mamiferos. Carecem de dentes, porém cada maxilar está coberto com uma escama epidérmica modificada que forma o bico, assim, não mastigam e apresentam uma região de armazenamento e embebição dos alimentos, o papo. As glândulas salivares e papilas gustativas estão pouco desenvolvidas e se abrem na base ou no teto da cavidade bucal (Weichert, 1965).

O comprimento do esôfago está relacionado com o comprimento do pescoço e está claramente separado do estômago (Weichert, 1965).

O estômago, adaptado para a trituração, se diferencia em duas regiōes, uma glandular ou proventrículo, que secreta muito suco gástrico e faz

\footnotetext{
${ }^{2}$ - Figueiredo R. 1996. Comunicação pessoal. Fazenda Billabong Avestruzes - Cezarina, Go, Brasil.
} 
uma pré-digestão dos alimentos, e a região muscular, a moela ou ventrículo (Swenon, 1988) que pode conter pedras ou areia, responsável pela moagem da digesta.

No intestino delgado, não existem áreas delimitadas como o jejum e o íleo dos mamíferos (Sturkie, 1968). O vestígio do saco vitelino (divertículo de Meckel) pode ser encontrado mais ou menos na metade do intestino delgado. As vilosidades geralmente são mais altas, delgadas e mais numerosas.

O intestino grosso é relativamente curto e não é bem demarcado em reto e cólon, como nos mamíferos, terminando na cloaca. Os cecos em geral, são em número par, suas dimensões são influenciadas pelos hábitos alimentares e eles não estão presentes em todas as espécies (Swenon, 1988). O pâncreas e o fígado também estão presentes auxiliando a digestão (Sturkie, 1968).

\subsubsection{Anatomia e fisiologia digestiva das Ratitas}

Das Ratitas, a ema, o avestruz e o emu são as aves mais pesquisadas. Os resultados dos estudos mostraram que os órgãos que compõe o aparelho digestivo incluem o bico, glândulas salivares, uma língua grossa, esôfago, proventrículo, ventrículo, intestino delgado, intestino grosso, ceco, reto e cloaca.

Fowler (1991) observou que o esófago, situado à direita do pescoço, entra diretamente no proventrículo dentro da cavidade toráxica. Em contraste com outras aves, as Ratitas não possuem papo (Jensen et al., 1992).

$\mathrm{Na}$ ema, o proventrículo (estômago glandular) é uma estrutura pequena, dilatada, de paredes relativamente delgadas, situada cranialmente 
ao ventriculo e a área secretora está limitada por uma emenda grossa, localizada dorsalmente (Fowler, 1991). No emu e nos casuares, o proventrículo é uma protuberância ampla, em forma de fuso, que circunda o lume central do trato digestivo, e a região glandular é mais pronunciada no emu do que nos casuares (Cho et al.,1984). No avestruz, este órgão é proporcionalmente o maior das as Ratitas e tem a menor região glandular, que se origina perto da junção com o esôfago e se estende ventrocaudalmente. Possivelmente seja nessa única espécie das Ratitas, que esse orgão tenha uma função tanto glandular como mecânica (Cho et al., 1984). A extremidade distal do proventrículo passa pelo ventrículo dorsal e se esvazia dentro do ventrículo caudal (Fowler, 1991).

Em contraste com a maioria das aves nas quais a superfície interior do proventrículo secreta enzimas digestivas, a função secretora das enzimas ácidas nas Ratitas está restrita à curvatura maior (Fowler, 1991).

O ventrículo no emu e casuares é um órgão que não apresenta uma forte musculatura (Cho et al., 1984) sendo diferente das outras Ratitas. No avestruz o ventrículo apresenta paredes grossas, similar aos ventrículos das aves que comem sementes e está situado a esquerda da linha média do corpo na borda caudal ao esterno. A abertura entre o proventrículo e o ventrículo é ampla, possibilitando a extração de corpos ventriculares através da incisão feita no proventrículo. Embora o ventrículo e proventrículo contenham normalmente pequenas pedras, a impactação é comum, particularmente nos animais jovens Fowler (1991). O mesmo autor observou que na ema o ventrículo é alargado e situado levemente a esquerda da linha média do corpo e mais caudal ao esterno que no avestruz.

$\mathrm{Na}$ ema, avestruz e emu o revestimento do proventrículo e do ventrículo é resistente e escuro (Jensen et al., 1992). Este revestimento ("koilin"), está formado pelas proteínas secretadas pelas glândulas e restos 
celulares presentes nestes órgãos, e a cor amarelo e esverdeada surge do refluxo de pigmentos biliares do duodeno (Fowler, 1991). Na Figura 1, podese observar as diferenças anatômicas, acima descritas, do ventrículo e proventrículo da ema, do avestruz e do emu.

O orifício no intestino delgado para a entrada do ventrículo está à direita em todas as espécies e ocupa a maior parte caudal do abdome. A primeira parte do intestino delgado nas Ratitas forma uma curva envolvendo o pâncreas, volta na região do estômago e continua caudalmente. Fowler (1991), observou que só no avestruz se forma uma curva duodenal secundária (Figura 2). No avestruz e na ema, o íleo é facilmente localizável na cavidade mesentérica, entre os cecos e o intestino grosso, na junção íleo-ceco-retal. 


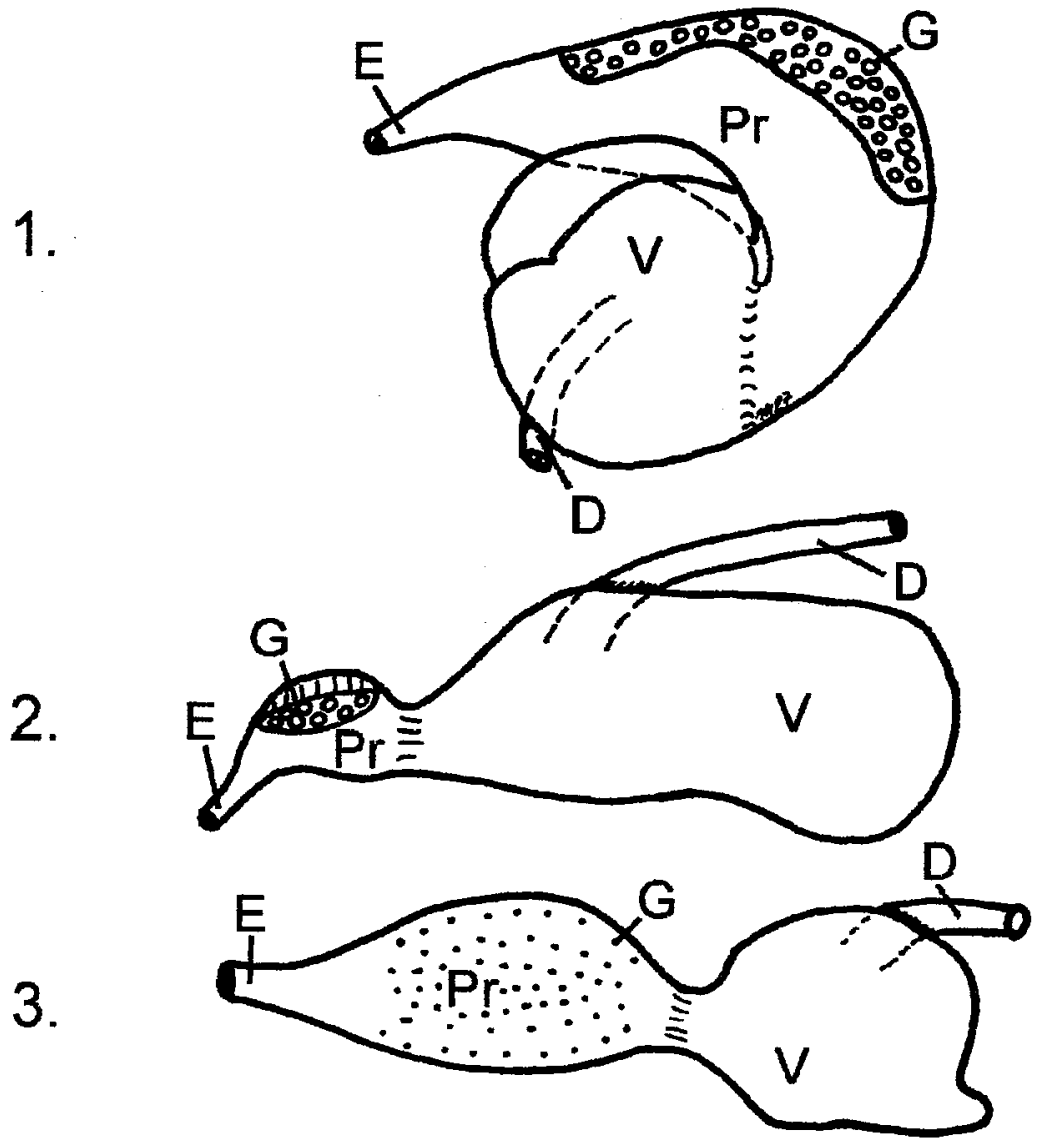

Figura 1: Estômago das Ratitas. 1-avestruz; 2- ema; 3-emu e casuares. G: área glandular do proventrículo. D: duodeno. E: esôfago. Pr: proventriculo. V: ventriculo. Fonte: Fowler (1991). 


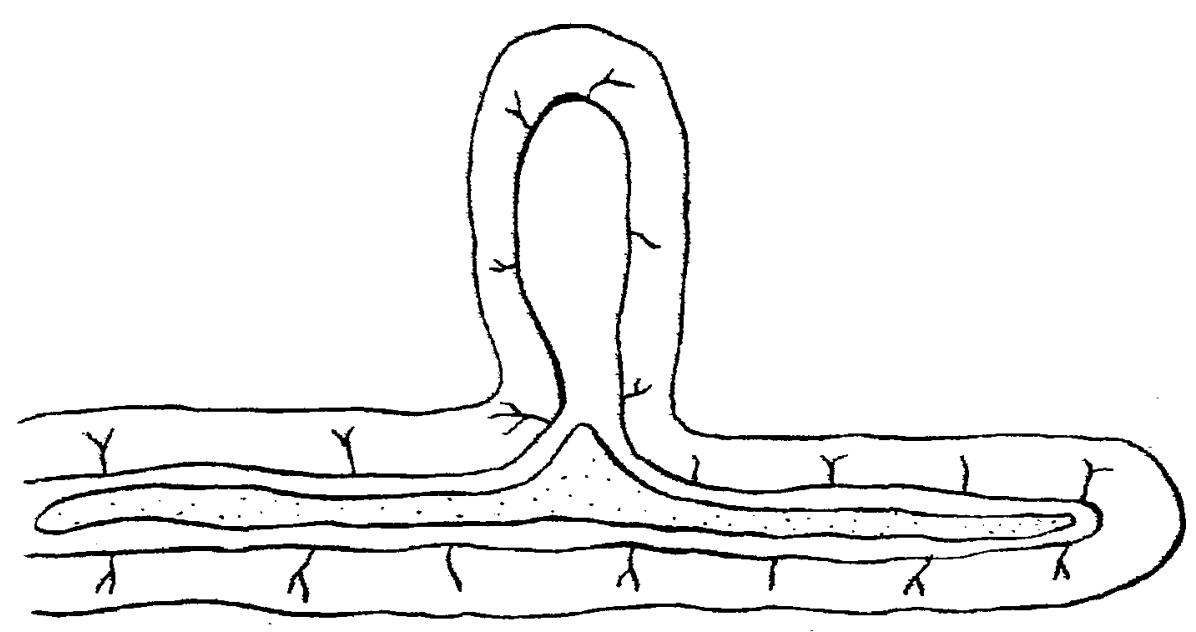

Figura 2: Curva duodenal secundária envolvendo o pâncreas no avestruz. Fonte: Cho, et al.( 1984).

Jensen et al. (1992) descrevem que os cecos são pares e a longitude varia consideravelmente nas Ratitas. Anatomicamente são alargados, bem desenvolvidos e saculados, com dobras em espiral (McLelland, 1989). Já no emu e nos casuares, os cecos são curtos e não funcionais (Fowler, 1991). Entre todas as Ratitas a ema apresenta o maior ceco e o avestruz o maior intestino grosso, enquanto que no emú ambos os órgãos são bem curtos (Jensen et al., 1992). As dimensões relativas dos intestinos e cecos da ema, avestruz e emu, são apresentados comparativamente na Tabela 1.

Segundo Jensen et al. (1992), a cloaca nas Ratitas é o orificio comum para as excreções do trato urinário e $\mathrm{o}$ trato digestivo. $\mathrm{O}$ reto do avestruz é volumoso e ocupa a região direita caudal do abdome (Fowler, 1991). O reto entra no coprodeo, saco dilatado e grande, separado pela prega retocoprodial. O coprodeo e o urodeo estão parcialmente separados por uma dobra coprourodeal. O urodeo é curto e dentro deste compartimento se 
encontram: os orifícios para as uretras, o oviduto das fêmeas e os vasos deferentes dos machos que eliminam seus produtos ao exterior, e o proctodeo é o orifício comum onde se eliminam as fezes e urina (Jensen et al., 1992). A bolsa de Fabrícius é parte integral da parede dorso lateral do proctodeo e na ema, é um apêndice cranial pequeno, no avestruz e no emu provavelmente são estruturas primitivas (Cho et al., 1984).

Tabela 1 : Comprimento relativo dos intestinos e cecos das Ratitas

\begin{tabular}{|c||c||c||c||c||}
\hline ESPÉCIE & IDADE & $\begin{array}{c}\text { INTESTINOS } \\
\text { Delgado } \\
\text { e Grosso } \\
(\mathrm{cm})\end{array}$ & $\begin{array}{c}\text { CECO } \\
(\%)\end{array}$ & $\begin{array}{c}\text { INTESTINO } \\
\text { GROSSO } \\
(\%)\end{array}$ \\
\hline \hline Avestruz & 30 dias & $283 \mathrm{~cm}$. & 6 & 57 \\
\hline \hline Ema & 40 dias & $163 \mathrm{~cm}$. & 28 & 19 \\
\hline \hline Emú & 100 dias & $379 \mathrm{~cm}$. & 2 & 7 \\
\hline
\end{tabular}

Fonte: Cho, et al. (1984). 


\subsection{Digestão}

\subsubsection{Digestão nas Ratitas.}

Os processos da digestão incluem a deglutição, maceração, moagem do alimento no estômago, ação de enzimas digestivas da saliva, do estômago, dos intestinos, do pâncreas e do bile, e também da ação de microrganismos (Sturkie, 1968). Este processos ocorrem normalmente nas Ratitas só que existem diferenças especificas como a habilidade destas aves para utilizar a fibra (Muirhead, 1995).

A digestibilidade dos diferentes nutrientes realizada pelas aves é um bom indicador de quanto o animal pode processar a partir da dieta. Em Ratitas, existem poucas informações na literatura relacionando a digestibilidade dos nutrientes. Na ema, por exemplo, o trabalho de Ansarah et $\mathrm{al}^{3}$., citado por Giannoni (1996), possivelmente seja o único estudo sobre fontes de volumosos verdes aproveitando a peculiar característica destas aves apresentarem um ceco funcional.

Os produtos finais da digestão microbiana são os ácidos graxos voláteis (ácido acético, propiônico e butírico) que são prontamente absorvidos e utilizados pelo animal como fonte de energia. Quando foi medido no avestruz a produção destes ácidos no estômago, intestino delgado, ceco e intestino grosso, os resultados mostraram que a produção de acetato foi mas ativa no intestino grosso (Muirhead, 1995).

Angel (1993) determinou em avestruzes de 3, 6, 10, 17 e 120 semanas de jdade, a digestibilidade da energia metabolizável (EM), ácidos graxos e fibra detergente neutro (FDN) na dieta, fornecendo $7 \%$ de ácidos

\footnotetext{
${ }^{3}$ Ansarah, C. et al. Pesquisa em andamento, 1996.
} 
graxos, $16,6 \%$ de fibra bruta $33,3 \%$ de FDN e a EM foi baseada na ração para aves domésticas $(1.983 \mathrm{kcal} / \mathrm{kg}$ ), utilizando como marcador indigestivel o óxido de cromo. $O$ autor observou que a digestibilidade da fibra foi menor com 3 semanas de idade, tendo um incremento linear a partir da 10 semana de idade. A digestibilidade de ácidos graxos nos animais de 3 semanas de idade foi menor que nos de 6 semanas de idade $(44,1 \%$ versus $73,3 \%$, respectivamente) e o autor concluiu que 0 avestruz de 10 semanas de idade teve habilidade de digerir mais de $50 \%$ do FDN da dieta e isto contribui para uma alta EM, comparado com a calculada. Do estudo da digestibilidade, o autor sugere que as dietas dos avestruzes adultos não devem ser formuladas usando-se valores de EM das aves domésticas, porque subestimam o valor de energia.

Os coeficientes de digestibilidade obtidos por Swart et al. (1993) em filhotes de avestruz em crescimento foram de $47 \%$ para FDN, $66 \%$ para hemicelulose e $38 \%$ para celulose, observando que estes animais são capazes de efetuar fermentação similar aos ruminantes (Scheideler \& Angel, 1994). Um meio microbiano saudável é muito importante para uma adequada digestão da fibra em Ratitas (Muirhead, 1995).

A habilidade de digerir a fibra pelo emu foi observada por Herd \& Dawson (1984), onde a major parte da energia é produzida pela digestão fermentativa da fibra detergente neutro (FDN) acima de $63 \%$ do padrão metabólico, onde o principal local de fermentação nestas aves é a parte distal do intestino delgado, no íleo. A taxa de passagem também foi medida pelo autor, registrando uma taxa de 5.5 horas nos adultos de emu. No avestruz, a taxa de passagem varia entre 21 a 76 horas ( Swart et al., 1993). 


\subsubsection{Alimentação em cativeiro da ema}

Foi observado que a fisiologia digestiva das Ratitas é bem diferente daquela das espécies de aves domésticas, sendo maiores as exigências nutricionais.

Para avaliar o hábito alimentar dos fithotes de ema no Brasil, Durigan \& Garrido (1986) testaram a aceitação de diferentes alimentos e os mais bem aceitos foram os seguintes alimentos: insetos, minhocas, pão velho, arroz cozido, repolho, couve, almeirão. Os ingredientes recomendados para suplementar a ração para Ratitas incluem: alfafa, milho, aveia, farelo de soja, grãos secos, casca de arroz, trigo triturado, farinha de carne e osso, farinha de peixe, casca de ostra, leveduras, suplementos minerais e vitamínicos (Muirhead, 1995).

Existem diferenças nas concentrações dos nutrientes que constituem as dietas das Ratitas, na literatura, as maiores variações obseryadas para as emas são os niveis de energia (2.000 a $4.000 \mathrm{kcal}$ ), fibra $(7 \%$ a $40 \%)$, cálcio $(0,85 \%$ a $5,0 \%)$ e fósforo $(0,43 \%$ a $1,5 \%)$. Pesquisas atuais mostram que as exigências nutricionais da ema são semeihantes às do avestruz (Giannoni, 1996). Nos trabalhos consultados, as diferentes tendências dos principais nutrientes requeridos pelas emas são apresentados na Tabela 2 . 
Tabela 2 :Tendências dos principais nutrientes (\%) requeridos pelas emas.

\begin{tabular}{|c|c|c|c|c|c|c|}
\hline Autor-Ano & Proteína & Fibra & E.E. & Cálcio & Fósforo & Energia \\
\hline Lint et al. & $\min .21 \%$ & $\begin{array}{c}\max . \\
7 \%\end{array}$ & $\begin{array}{l}\min . \\
3,5 \%\end{array}$ & $2,5 \%$ & $1,0 \%$ & - \\
\hline $\begin{array}{l}\text { Flieg } \\
\text { (1973) }\end{array}$ & $19 \%$ & $18 \%$ & $2,7 \%$ & $1,78 \%$ & $0,67 \%$ & - \\
\hline $\begin{array}{l}\text { Jensen } \\
\text { (1989) }\end{array}$ & $18 \%$ a $23 \%$ & $\begin{array}{l}\max . \\
10 \%\end{array}$ & - & - & - & milho (1) \\
\hline $\begin{array}{l}\text { Jensen et al. } \\
\text { (1992) }\end{array}$ & $16 \%$ a $18 \%$ & $<10 \%$ & $<10 \%$ & $-2,5 \%$ & $\sim 1,5 \%$ & - \\
\hline $\begin{array}{l}\text { Saracura } \\
\text { (1993) }\end{array}$ & $20,1 \%$ & $10,6 \%$ & $3,93 \%$ & $0,86 \%$ & $0,43 \%$ & $\begin{array}{l}2.000 \\
\text { (kcal) }\end{array}$ \\
\hline $\begin{array}{l}\text { Dani } \\
\text { (1993) }\end{array}$ & $20 \%$ & $40 \%$ & $15 \%$ & $\begin{array}{l}1,5 \% \text { a } \\
2,5 \%\end{array}$ & $\begin{array}{c}1,0 \% a \\
1,5 \%\end{array}$ & $\begin{array}{l}4.000 \\
\text { (kcal) }\end{array}$ \\
\hline $\begin{array}{l}\text { Chapman \& } \\
\text { Bass } \\
\text { (1994) }\end{array}$ & $14 \%$ a $16 \%$ & - & - & $0,8 \%$ & $0,4 \%$ & - \\
\hline $\begin{array}{l}\text { Wolaj } \\
(1996)\end{array}$ & $20 \%$ & $9 \%$ & $2,50 \%$ & $2 \%$ & $1,50 \%$ & - \\
\hline
\end{tabular}

(1) milho: $3.400 / \mathrm{kcal}$. (Andrigueto et al., 1988)

\footnotetext{
${ }^{4}$ Wolaj, R. 1996. Comunicação pessoal. Bat lana Rhea Farm - Don Elias S.G. Salto - Uruguai.
} 


\subsection{Deformações das pernas}

\subsubsection{Aspectos gerais}

As deformações esqueléticas têm origem geralmente durante 0 período de crescimento (Coimbra-Filho \& Cruz Rocha, 1973). Os frangos de corte e perus têm sido as grandes vítimas deste problema, e a maior prevalência desta alteração parece indicar a falta de sincronismo entre o desenvolvimento da massa muscular e da estrutura óssea, indispensáveis para suportar o rápido crescimento da ave (Silva, 1984).

A incidência de desordens esqueléticas no sistema locomotor das aves confinadas, especialmente no frango de corte, não tem decrescido nos últimos quarenta anos, apesar de intensos esforços de pesquisas e pela dificuldade de muitos sintomas decorrentes das anormalidades ósseas, não são clinicamente visíveis (Tardin, 1995).

O sistema locomotor das Ratitas, em cativeiro, também é afetado pelas deformidades ósseas causadas primariamente por deficiências nutricionais, excessiva taxa de crescimento (Reece \& Butler, 1984) características genéticas, prática de exercício (Perelman citado por Jensen et al., 1992) e a incubação dos ovos (Kuehler \& Good, 1990; Wade, 1992).

No frango de corte, o aspecto nutricional, genético, de manejo e patológico, exercem influências significativas (Tardin, 1995).

A classificação das desordens do esqueleto são sempre difíceis e quase sempre arbitrárias, especialmente no que se relaciona com sua etiologia (Silva, 1984). Geralmente destacam-se as deformações angulares (valgus e varus), rotação da tíbia e a discondroplasia para o frango de corte (Tardin, 1995) e o deslizamento do tendão gastrocnêmio para as emas (Chapman \& Bass, 1994) e os avestruzes (Bezuidenhout \& Burger, 1993). Estas doenças 
que afetam os ossos das pernas nas aves Ratitas são descritos normalmente como deformidades das pernas (Guittin, 1986).

\subsubsection{A importância da nutrição e do exercício nas deformidades nas pernas das emas}

\subsubsection{Idade crítica}

As aves que apresentam os sintomas de deformidade nos ossos das pernas, não estão em condições de ser reintroduzidas na natureza e é duvidosa sua viabilidade para incluí-los em projetos de criação. Geralmente os primeiros sintomas de encurvamento no emu e avestruz, aparecem na quarta semana de idade. Na ema, durante a sexta e décima segunda semana de idade (Guittin, 1986), embora até os 3 meses de idade, tenham ocorrido numerosos casos (Chapman \& Bass, 1994), sendo este o período mas crítico (Fezler ${ }^{5} 1996$ ).

\subsubsection{Efeito da nutrição}

A nutrição é, possivelmente, a causa mais importante que afetaria a doença dos ossos (Dani, 1993).

Com o objetivo de conhecer os problemas de encurvamento das pernas em filhotes de ema, Bruning (1973), fez um estudo submetendo os filhotes a vários tratamentos diferentes, aplicando semanalmente injeções de complexo vitamínico mais vitamina $D_{3} e$ diariamente cápsulas de fosfato bicálcico, observando que as aves do grupo controle, que não receberam

${ }^{5}$ Fezler, D. 1996. Comunicação pessoal. Grand Cy Press Ranch. Jackson Ville. II. EEUU. 
nenhum suplemento, desenvolveram a doença. No grupo de animais alimentados separadamente e recebendo fosfato bicálcico pulverizado na ração, foram obtidos vários resultados: os filhotes que evitaram o alimento pulverizado cresceram rapidamente e desenvolveram o encurvamento das pernas, enquanto que os outros que consumiram o fosfato bicálcico não tiveram problemas, sugerindo que uma forma de prevenir a doença seria controlar a ingestão.

O desbalanceamento no metabolismo do cálcio, somado a um rápido ganho de peso, seriam as principais causas de encurvamento dos ossos nas emas (Guittin, 1986).

O osso é um tecido metabolicamente ativo $e$ as atividades que controlam o crescimento ósseo são a formação da matriz orgânica, sua mineralização e reabsorção óssea (Tardin, 1995). O cálcio e o fósforo pre sentes nos alimentos são absorvidos, principalmente no duodeno. A absorção do cálcio é favorecida pela forma ativa da vitamina $D_{3}$, que leva à formação de uma proteína transportadora de cálcio nas células epiteliais. Absorvido pelo intestino, o cálcio circula pelo corpo através do sistema porta, sendo prontamente retirado do sangue para sua utilização pelo osso, durante 0 periodo de crescimento (Swenon, 1988). Os níveis de cálcio plasmático são severamente controlados (Louvandini, 1995) pelos hormônios paratormônio, calcitonina e pela vitamina $D_{3}$.

O cálcio deve guardar uma relação com o fósforo, a ser mantida de modo constante para se evitar a desmineralização (Coimbra-Filho \& Cruz Rocha, 1973). Deve-se manter na dieta destas aves as seguintes proporções: o Ca:P 2:1 (Wallach, 1970; Flieg, 1973; Perelman, citado por Jensen et al., 1992).

Os filhotes que são alimentados com dietas altamente protéicas, apresentam um rápido crescimento (Jensen, 1989) e frequentemente à partir 
da segunda até a sexta semana de idade, observa-se o desenvolvimento da osteodistrofia e os fithotes não conseguem-se levantar e andar normalmente (Reece \& Butler, 1984). Gandini, citado por Jensen et al. (1992), para avaliar os niveis de proteina da dieta, conduziu um trabalho com filhotes de avestruz, no Jardim Zoológico Nacional da África do Sul, testando rações isocalóricas com diferentes niveis de proteína $14 \%, 16 \%, 18 \%, 20 \%$, contendo $1,4 \%$ de cálcio e $0,7 \%$ de fósforo. Nos resultados obtidos com $14 \%$ de proteína, o ganho de peso foi menor em relação aos outros três grupos, e com menor eficiência na conversão alimentar. Isto indica que niveis abaixo de $16 \%$ de proteína não são adequados para filhotes de avestruz. Os grupos com $14 \%$, $16 \%$ e $20 \%$ de proteína tiveram um pronunciado encurvamento do metatarso. O grupo alimentado com $18 \%$ de proteína não teve incidência deste problema. Jensen et al. (1992) baseando-se neste trabalho concluíram que os filhotes das Ratitas não requerem níveis de proteina acima de $18 \%$ em dietas com a energia e os nutrientes básicos em niveis apropriados. $O$ mesmo autor cita que por vários anos, as dietas com baixos niveis de cáicio ou com proporção de cálcio e fósforo inadequada, pode produzir desvios nos ossos longos em avestruz, ema e emu.

Uma excessiva taxa energética na ração pode contribuir também para síndrome de deformações nas pernas (Ulirey, citado por Guittin, 1986). Com o objetivo de recolher maiores informações sobre o problema de entortamento em filhotes de emas, Saracura (1993) forneceu às aves três rações contendo diferentes niveis de energia metabolizável $(2.000,2.400,2.800 \mathrm{kcal}$ de EM/kg de ração), concluindo que para o menor nivel de energia, as aves apresentaram um bom desenvolvimento, isentas do problema de entortamento das pernas.

Igualmente estão implicados nas doenças descritas em filhotes das Ratitas, o magnésio (Flieg, 1973; Wallach \& Boever, 1983; Jensen, 1989), o 
selênio e a vitamina D (Dolensek \& Bruning, 1986; Jensen et al., 1992), mas não foram realizadas pesquisas, ainda, especificando a gravidade do efeito na doença.

\subsubsection{Importância do exercício}

Bruning (1973) comparou o crescimento tíbio-tarsal em filhotes criados separados do macho em cativeiro, filhotes com o macho e filhotes na natureza, observando que a taxa de crescimento tibio-tarsal nas aves silvestres foi parecida com a observada em filhotes em cativeiro. $O$ peso de filhotes na natureza foi muito menor que o de filhotes em cativeiro mantidos junto ao macho. Este autor sugere que a falta de exercicio seria um fator predisponente ao entortamento das pernas. Os filhotes criados com uma ave adulta são obrigadas a realizar exercicio, evitando os problemas nas pernas (Hoctor, 1993).

Dolensek \& Bruning (1986); Jensen (1989); Jensen et al. (1992); Wade (1992), consideram que o entortamento das pernas nos filhotes de ema seja atribuido à deficiências nutricionais e à falta de exercício.

$\dot{E}$ importante considerar que as Ratitas tem, ao nascimento, grande massa cartilaginosa na porção proximal dos ossos das pernas. Estes filhotes retém esta massa de origem embrionária até a sexta semana de idade (Reece \& Butler, 1984). Essa característica pode explicar porque deve-se evitar o excessivo ganho de peso dos filhotes durante esta fase.

Outro fator que poderia estar envolvido na doença seria o estresse (Coimbra-Fitho \& Cruz Rocha, 1973; Jensen et al., 1992) que o animal sofre quando é mantido em áreas muito pequenas timitando suas atividades.

O tipo de piso em que os fithotes são mantidos é outro fator a ser considerado. Filhotes criados sobre substrato semelhante ao da natureza não 
apresentaram sintomas (Bruning, 1973, Bianchini' 1996; Smith, 1993).

Pelas informações das pesquisas sobre o encurvamento de pernas em fithotes de ema, verifica-se que existem controvérsias na literatura a respeito das suas causas, havendo necessidade de se realizar maiores estudos a respeito do problema em questão.

${ }^{6}$ Biachini, J. 1996. Comunicação pessoal. Faculdad de Ciencias Naturales y Museo de La Universidad Nacional de La Plata. Buenos Aires. Argentina. 


\section{MATERIAL E MÉTODOS:}

\subsection{Animais experimentais}

Os filhotes de ema Rhea americana americana foram emprestados, pelo Parque Ecológico de São Carlos, localizado na cidade de São Carlos-SP e transportados dentro de caixas de papelão forradas com capim seco, até a Escola Superior de Agricultura "Luiz de Queiroz", Universidade de São Paulo, (ESALQ/USP) de Piracicaba -SP com prévia autorização do Instituto Brasileiro de Meio Ambiente e Recursos Naturais Renováveis (IBAMA).

As emas foram identificadas ao inicio do experimento, com marca de couro de cores diferentes na base do tibiotarso. Após esta identificação foram sorteados os filhotes, os piquetes e as dietas experimentais.

\subsection{Local}

\subsection{1 Área pré-experimental}

$\mathrm{Na}$ primeira etapa foram utilizadas as gaiolas do galpão do Aviário Experimental do Departamento de Zootecnia ESALQ/USP para a adaptação dos animais. Estas apresentavam chão de cimento, lâmpadas para aquecimento, bebedouros e comedouros de latão pendurados do teto. As laterais do galpão eram cobertas por uma cortina de plástico amarelo, com um 
sistema de polia para abrir e fechar. As gaiolas foram previamente lavadas com água sanitária e desinfetadas com "vassoura de fogo".

\subsection{2 Área experimental}

$\mathrm{Na}$ etapa experimental os 11 animais foram colocados nos piquetes do Departamento de Zootecnia da ESALQ/USP. Os piquetes de $100 \mathrm{~m}^{2}$ apresentavam uma área coberta de $10,21 \mathrm{~m}^{2}$ com chão de cimento, onde foi colocada uma gaiola com capim seco para os animais dormirem a noite. Foram construídas valetas para prevenir a entrada de água dentro desta área coberta e também foi utilizada uma tela preta para proteção da chuva, vento, frio e possiveis predadores noturnos. Os comedouros de latão, foram pendurados no teto da área coberta, para impedir que a ração ficasse no chão ou fosse pisoteada pelo animais, e evitando perdas facilitando a alimentação dos animais, a determinação do consumo diário. Os piquetes experimentais foram capinados e desinfetados com cal (Anexo A, Figura 1 e 2).

$\mathrm{Na}$ área onde se localizavam os piquetes se encontravam catetos Tajassu tajacu, gambás Dydelfis marsupial soltos que normalmente tentam entrar nas baias. Para a segurança das emas, se decidiu reforçar todos os alambrados de arames dos recintos, incluindo os que dividem os piquetes e as portas, com tela para pintinhos. Além disso, esta tela impediriấ que as emas ficassem presas ou que se machucassem no manejo diário. Foi colocada uma tela branca com aproximadamente 80 a $100 \mathrm{~cm}$ de altura para impedir que qualquer outro animal visse os filhotes.

\subsection{Delineamento experimental}

Os animais foram dispostos nos seis piquetes e junto aos dois tratamentos foram distribuídos ao acaso, resultando três repetições para cada 
nivel de tratamento. Assim, o delineamento experimental foi inteiramente casualizado, seguindo um modelo matemático para as variáveis de resposta (peso do animal, consumo diário de ração e comprimentos do bico, do tibiotarso e do metatarso).

As análises da variância para as variáveis de resposta: peso do animal, consumo e medidas de crescimento, foram realizadas no Statistical Analysis System (S.A.S, 1986), com prévias análises exploratórias para observar as présuposiçōes requeridas por esta técnica. Quando alguns dos requisitos não foram satisfeitos para as características avaliadas, uma análise da variância não paramétrica, (Teste de Wilcoxon), foi escolhido.

A fim de verificar a existência de associação linear entre o peso do animal e o consumo diário, e o peso do animal e as variáveis de crescimento, foram realizadas, no S.A.S., análises de regressão linear e obtidas as equações de predição.

\subsection{Dieta}

\subsubsection{Dieta pré-experimental}

Inicialmente a ração fornecida foi a mesma utilizada no Parque Ecológico de São Carlos, constituída de uma mistura de: ração inicial para pintinhos, ovos cozidos, couve ou chicória. Após uma semana os ovos foram substituídos por carne de vaca moída, devido a melhor aceitação pelos filhotes. Quando foi necessário estimular o apetite foi utilizado, em duas ocasiōes, o Vitagold Potenciado (Tortuga $-1 \mathrm{ml} \times 1,5 \mathrm{l}$ de água). Utilizou-se 0 Vionate $\mathrm{P}$ (Ciba-Geigy Quimica) como suplemento mineral (5 $\mathrm{g} \times 1.100 \mathrm{~kg}$ ) pulverizado na ração. 


\subsubsection{Dieta experimental}

Neste trabalho foram testadas duas rações, fornecidas peletizadas, com diferentes níveis de Cálcio. $\mathrm{Na}$ Tabela 3, são apresentados as quantidades de ingredientes que as constituem. As rações foram balanceadas pela SUPRE MAIS PRODS. BIOQ. LTDA., a Tabela 4 mostra as composições bromatológicas, obtidas após a revisão de literatura.

\subsection{Manejo}

Tanto na etapa pré-experimental como na etapa experimental, a água e a ração foram fornecidas diariamente "ad-libitum", sendo determinado o consumo alimentar. Também diariamente foi feita a limpeza de cada piquete e quando necessário, a troca do capim seco das camas. Foram realizadas avaliações do comportamento das atividades dos animais e a sanidade dos animais foi controlada por um médico veterinário.

\subsubsection{Manejo pré-experimental}

Nesta etapa, que durou cerca de 30 dias, as lâmpadas de aquecimento eram ligadas entre as 18:00 e 19:00 hs, permanecendo ligadas durante a noite, sendo desligadas entre 8:00 e 8:30 hs da manhã seguinte.

No último dia desta etapa, os filhotes foram presos fortemente pelas patas e rapidamente colocado numa caixa de papelão, onde foram pesados. Foram tomadas as medidas do comprimento do bico, dos ossos tibiotarso e metatarso. 
Tabela 3: Quantidade de ingredientes utilizados na preparação dos dois tratamentos.

\begin{tabular}{|l||c|c|}
\hline \multicolumn{3}{|c|}{ INGREDIENTES } \\
\hline \multicolumn{1}{|c|}{ Ingredientes } & Tratamento & Tratamento \\
& 1 & 2 \\
\hline Milho & $34,94 \%$ & $34,94 \%$ \\
\hline Farelo de trigo & $29,70 \%$ & $29,70 \%$ \\
\hline Farelo de soja & $20,70 \%$ & $20,70 \%$ \\
\hline Farinha de carne & $2,51 \%$ & $2,51 \%$ \\
\hline Calcário & $0,70 \%$ & $2,60 \%$ \\
\hline Casca de arroz & $4,90 \%$ & $4,90 \%$ \\
\hline Óleo vegetal & $0,50 \%$ & $0,50 \%$ \\
\hline Sal & $0,45 \%$ & $0,45 \%$ \\
\hline Caulim & $5,10 \%$ & $3,20 \%$ \\
\hline Supl. mineral e vitamínico & $0,50 \%$ & $0,50 \%$ \\
\hline
\end{tabular}

Suplemento mineral / $\mathrm{Kg}$ de ração: Manganês $80 \mathrm{mg}$; Zinco $40 \mathrm{mg}$; Ferro $180 \mathrm{mg}$; Cobre 30mg; lodo 4mg; Selênio $0,1 \mathrm{mg}$; Cobalto $4 \mathrm{mg}$.

Suplemento vitamínico / Kg de ração: Vit. A 12.000Ul; Vit. D3 1.500Ul; Vit. B2 5mg; Vit. E 22mg; Vit. B1 12mg; Vit. B6 4mg; Pantotenato de Cálcio 15mg; Biotina $0,1 \mathrm{mg} ; \mathrm{K} 34 \mathrm{mg}$; Ácido fólico $0,6 \mathrm{mg}$; Metionina 100mg; Lisina 300mg; BHT 10mg; Vit.B12 20 microgramas; Niacina 20mg; Colina 100mg. 
Tabela 4: Composição bromatológica calculada dos dois tratamentos.

\begin{tabular}{|c||c|c||c||c||c||c|}
\hline DIETA & PB & FB & EE & CA & P & $\begin{array}{c}\text { EM } \\
(\mathrm{kcal} / \mathrm{kg})\end{array}$ \\
\hline \hline $\begin{array}{c}\text { tratamento } \\
1\end{array}$ & $18,3 \%$ & $6,85 \%$ & $6,80 \%$ & $0,7 \%$ & $0,6 \%$ & $\begin{array}{c}2.235 / \\
\mathrm{kcal}\end{array}$ \\
\hline $\begin{array}{c}\text { tratamento } \\
2\end{array}$ & $18,3 \%$ & $6,85 \%$ & $6,80 \%$ & $1,4 \%$ & $0,6 \%$ & $\begin{array}{c}2.235 / \\
\mathrm{kcal}\end{array}$ \\
\hline
\end{tabular}

\subsubsection{Manejo experimental}

Nesta etapa, diariamente as gaiolas eram abertas entre as 7:00 e 8:30 hs e fechadas as 19:00 e 20:00 hs. As pesagens foram realizadas semanalmente, o animal era retirado diretamente da gaiola, eram tomadas as medidas do bico, tibiotarso e metatarso, e levados na caixa de pesagem para fora do piquete $e$ após a pesagem soltos novamente no local. Para essa atividade de contenção foi fixado um tempo máximo de 5 minutos com o objetivo de não ocasionar estresse nos filhotes que eram contidos fortemente pelas pernas, acompanhando o movimento das pancadas para não produzir nenhum tipo de lesão ou fraturas. Uma vez solto o animal mantinha sua atividade normal.

No final desta etapa foi realizada a sexagem dos filhotes, através da técnica de reversão de cloaca. Também foram colhidas amostras do sangue dos filhotes em jejum, sendo que foram necessárias duas pessoas para a contenção, o veterinário e um ajudante. A colheita foi feita na veia radial da 
asa, com a punção direta em seringa de $10 \mathrm{ml}$ e agulha de $13 \times 4,5 \mathrm{~mm}$ (tipo insulina) com uma gota de heparina. $O$ volume de sangue colhido foi de $1,5 \mathrm{ml}$ a 3,5 ml dificultando a colheita a movimentação do animal. Uma vez liberado o animal recuperava suas condiçōes normais de comportamento em aproximadamente 10 minutos.

Após 4 dias, era feita nova coleta, utilizando um "butterfly" (Becton Dickinson -27g) e o corpo do animal era contido com um pano obtendo-se assim maior conforto ao animal e possibilitando a retirada de maior volume de sangue.

\subsection{Análises Clínicas}

As colheitas de sangue de cada animal foram feitas ao final do experimento para determinação de Hematócrito, Hemoglobina e a obtenção de plasma para a determinação de fósforo e de selênio.

As análises de cálcio foram feitas no Centro de Energia Nuclear na Agricultura (CENAVUSP) na Seção de Química Analítica, sob a responsabilidade do Prof. Dr. Boaventura Freire do Reis, utilizando a técnica de espectrometria de absorção atômica com chama (FAAS). Também foram feitas nesta seção as análises de selênio utilizando a técnica de determinação de selênio por geração de hidreto. As análises de fósforo foram realizadas no CENAJUSP, na Seção da Ciências Animais sob a responsabilidade do Prof. Dr. Adibe Luiz Abdalla, utilizando a técnica de Fiske \& Subbarow (1925) para a determinação do fósforo em plasma e a técnica de vanadato e molibdato para determinação em tecidos.

Foram realizadas as análises de Hemoglobina, medida através de uma fita de papel Hawksley Haemoglobin Scale. A determinação de Hematócrito feita através da centrífuga para micro hematócrito. 


\subsection{Radiografias}

Foram realizadas ao final da etapa experimental, radiografias do tibiotarso e metatarso dos filhotes, de cada dieta, para avaliação da mineralização óssea. As radiografias foram feitas na Clínica Veterinária Frasson Ltda, na cidade de Piracicaba - SP .

\subsection{Exame de matéria fecal}

Foram feitas semanalmente coletas de material fecal, para o controle parasitário dos animais. O exame das fezes foi realizada através do método de flutuação simples da técnica de Willis (Willis, 1927).

\subsection{Medição do deslocamento}

O deslocamento dos animais foi medido através do Método de Amostragem "Scan Sampling" (Martin \& Bateson, 1986), em intervalos de 5 minutos distribuídos no horário das 8:30 até as 19:00hs. Este método consiste em observar o animal, descrevendo sua atividade nos intervalos estabelecidos. As observações foram feitas aproximadamente a 4 metros de distância dos piquetes. Estas observaçōes permitiram conhecer as atividades diárias realizadas pelo filhotes em cativeiro, avaliando desta forma o exercício. As observações foram analisadas, primeiramente para cada animal, após para cada piquete e por último, para cada dieta utilizada. A finalidade disso foi observar tendências de comportamento individuais, no seu grupo e por tratamento imposto neles. O comportamento foi usado como variável categórica, com 11 pautas comportamentais, à saber: 
1- bebendo do bebedouro.

2- bicando o chão, plantas, telas de arames, paredes.

3- brigando.

4- caminhando, deslocando-se em qualquer direção.

5- comendo do comedouro.

6- correndo, deslocando-se em qualquer direção.

7- deitado, descansando.

8- dormindo.

9- parado.

10- sentado.

11- correndo em ziguezague (deslocamento típico da espécie).

A cada cinco minutos foi registrado se o animal realizava alguma das onze pautas. Com as contagens, ao longo do tempo estabelecido como de amostragem, foram construídos gráficos ilustrativos desse comportamento e obtidas as porcentagens como medidas descritivas para cada pauta comportamental.

\subsection{Mortalidade pré-experimental}

$\mathrm{Na}$ etapa pré-experimental ocorreram várias mortes de filhotes. As necrópsias foram feitas dentro das 24 hs, para determinar a "causas mortis" e colheita de tecidos para a realização do estudo histopatológico e análises de minerais. $O$ estudo das informações obtidas nas necropsias (selênio no fígado, cálcio no osso, fósforo no osso e no músculo) forneceram aportes valiosos na construção do conhecimento da espécie. As análises histopatológicas foram feitas na Universidade Estadual Paulista, Câmpus de Jaboticabal (UNESP), Departamento de Patologia Veterinária, pela Profa.Dra. Karen Werther. 


\section{RESULTADOS E DISCUSSÃO}

No final do experimento foi realizada a sexagem dos filhotes através da técnica de reversão de cloaca, que é muito utilizada nas Ratitas (Anon, 1995) para a visualização do pênis, localizado na porção ventral do proctodeo (Fowler, 1991). Esta técnica possibilitou com facilidade e exatidão a identificação de 5 machos e 6 fêmeas. A sexagem pelo DNA ou pelo cariótipo reduz os riscos do estresse da ave, mas nas emas as técnicas citogenéticas de bandeamento apresentaram-se ineficientes para a sexagem através do cariótipo (Gunski, 1992). Ao contrário da maioria das aves analisadas citogeneticamente, nas Ratitas o cromossoma " $W$ " das fêmeas não parece ser diferente do cromossoma " $Z$ " do macho. A confirmação do sexo para os avestruzes, pelo método do DNA nos Estados Unidos (Giannoni, 1996).

Dos exames feitos nas amostras de fezes, colhidas semanalmente dos filhotes, verificou-se a presença de numerosas formas ovaladas, características de ovos de Helmintos, em uma amostra, apenas. Não havendo a possibilidade de identificar gênero e espécie do ovo, decidiu-se tratar os animais com o vermífugo para aves domésticas "Proverme" (nome comercial), onde o principio ativo é o citrato de piperazina tetrahidratado, solúvel em água que foi ministrado na dosagem de $0,07 \mathrm{~g}$ do produto por quilo de peso vivo animal, com uma seringa pelo bico do filhote parasitado. Esta terapia foi repetida após 15 dias. O controle foi realizado até a última semana do experimento, sendo negativos todas as análises. Tratamentos com piperazina 
são recomendados contra ascarídeos e tiabendazole ou mebendazol contra strongilídeos (Dani, 1993)

Para a avaliação da mineralização óssea, em duas ocasiōes, 2 filhotes de cada uma das dietas foram levados para a Clínica Veterinária. Os filhotes foram previamente sedados, utilizando $3 \mathrm{ml}$ de cloridrato de cetamina por quilo de animal (Ketalar), para diminuir o estresse durante o transporte dos filhotes e facilitar a contenção dos mesmos na exposição do Rx. Verificou-se uma excitação inicial das aves, demostrando a necessidade de se fazer uma associação com outro sedativo (Jensen et al., 1992).

As colheitas de sangue para a determinação de Hematócrito (Htc), Hemoglobina $(\mathrm{Hb})$ e fósforo no plasma, foram feitas na veia radial da asa. $A$ colheita de sangue feita na veia do metatarso é outra forma, permitindo que a contenção da ave seja mas confortável. Não houve efeito significativo nos níveis do Hematócrito e de Hemoglobina com relação ao sexo do filhote. Embora não tenham sido observados diferenças estatísticas significativas, verificou-se uma tendência para valores de Hematócrito serem maiores nas fêmeas que os machos em ambos tratamentos (Tabela 5). O valor de Hematócrito observados por Fernandez de Oliveira ${ }^{7}$ (1996) foi de $40 \%$ para emas, e os valores obtidos para Hemoglobina foram de 10 a $14 \%$ (Dolensek \& Bruning, 1986) . Jensen et al. (1992) observaram em filhotes de avestruz, valores entre 10 e $20 \%$ de Hemoglobina a média observada de $12,2 \%$. No entanto (Juncker, 1993) observou os valores de $30,4 \%$ para Hematócrito e de $12,16 \%$ para Hemoglobina. Os valores obtidos pelos autores são semelhantes aos obtidos nos filhotes de ema neste trabalho.

\footnotetext{
${ }^{7}$ Fernandez, de Oliveira. 1996. Comunicação pessoal. Companhia Brasileira de Metalurgia e MIneração.
} 
Tabela 5: Valores médios e desvio padrão obtidos para Hemoglobina e Hematócrito em sangue, para cada sexo e dieta, em filhotes com aproximadamente 90 dias.

\begin{tabular}{|c|c|c||c|c|}
\hline Parâmetros & $\begin{array}{c}\text { MACHOS } \\
\text {-dieta 1- }\end{array}$ & $\begin{array}{c}\text { MACHOS } \\
\text {-dieta 2- }\end{array}$ & $\begin{array}{c}\text { FÉMEAS } \\
\text {-dieta 1- }\end{array}$ & $\begin{array}{c}\text { FÊMEAS } \\
\text { - dieta 2- }\end{array}$ \\
\hline $\mathbf{H b}(\mathbf{g} / \%)$ & $12,48 \pm 2,21$ & $12,48 \pm 2,38$ & $12,48 \pm 1,80$ & $14,85 \pm 1,10$ \\
\hline $\mathbf{H t c}(\%)$ & $33,00 \pm 1,41$ & $33,50 \pm 8,50$ & $36,25 \pm 3,40$ & $37,50 \pm 4,95$ \\
\hline
\end{tabular}

Os valores obtidos de fósforo no plasma são apresentados na Tabela 6. Os valores observados por Jensen et al. citado por Jensen et al. (1992) 5,23 mg/\% para o avestruz e 3,66mg/\% para o emu. Okotie-Eboh et al. (1992) obteve $5,2 \mathrm{ml} / \%$ para o avestruz e $5,4 \mathrm{ml} / \%$ para o emú. Os valores mínimos e máximos observados por Hodges citado por Jensen et al. (1992) foram de 4,0\% a 9,9\% para os avestruzes. Estes valores sugerem que os valores obtidos nos filhotes de ema neste trabalho, estão dentro dos parâmetros observados para outras espécies do grupo das Ratitas. 
Tabela 6: Valores de fósforo obtidos no plasma de filhotes de ema com aproximadamente 90 dias.

\begin{tabular}{|l||c||c||c||c|c||c||c||c||c||c||c||}
\hline animal & A & B & C & D & $E$ & $F$ & $G$ & $H$ & $M$ & $P$ & $R$ \\
\hline \hline fósforo \% & 4,16 & 2,80 & 4,29 & 6,30 & 4,88 & 5,99 & 5,71 & 4,56 & 6,84 & 3,33 & 4,44 \\
\hline dieta & 1 & 1 & 2 & 1 & 1 & 1 & 1 & 2 & 2 & 2 & 2 \\
\hline
\end{tabular}

Ocorreram 18 óbitos de filhotes de ema com 5 a 30 dias de idade na etapa pré-experimental com "causas mortis" divididas em : 13 óbitos por septicemia, 3 óbitos ocasionados por indigestão e 2 óbitos ocasionados pela fratura do osso fêmur direito. Os resultados das exames histopatológicos dos 13 óbitos por septicemia são apresentados na Tabela 7.

A mortalidade dos filhotes das emas é considerada alta e as principais causas dos óbitos são: doenças gastrintestinais, infeções do saco vitelino, doenças no fígado, desordens hemocitopoética e doenças respiratórias (Jensen et al., 1992; Chapman \& Bass, 1994). Algumas destas causas também foram observadas na maioria dos óbitos ocorridos nos filhotes de ema, neste trabalho.

A impactação ocorre quando há um acúmulo de digesta no ventrículo e o proventrículo, sem que haja passagem para o intestino delgado (Wade, 1992). A impactação é frequente nos animais jovens nas Ratitas, sendo muito 
comum nos filhotes de avestruz ( Shwaluk \& Finley, 1995). Uma das causas que a provocaria seria o estresse, que levaria o animal a se alimentar excessivamente (Smith, 1993). A impactação do ventrículo ou moela também foi observado na ema ( Sanford \& Rehmtulla, 1993). No dia que os animais sofreram a impactação, estavam sendo levados à área experimental, e possivelmente, o estresse do manejo afetou esses filhotes que incontroladamente comeram terra (achada na necropsia), provocando a impactação.

Tabela 7: Resultados obtidos ao exame histopatológicos dos 13 óbitos ocorrido por septicemia nos filhotes de ema.

\begin{tabular}{|c||l|}
\hline Número de óbitos & Achados de necrópsia \\
\hline 2 & pneumonia + hepatite \\
\hline 3 & pneumonia + hepatite + enterite \\
\hline \hline 1 & pneumonia + hepatite + miocardite \\
\hline \hline 1 & pneumonia + hepatite + miocardite + enterite \\
\hline \hline 5 & pneumonia + hepatite + enterite + nefrite \\
\hline \hline 1 & pneumonia + hepatite + enterite + miocardite + nefrite \\
\hline
\end{tabular}

As fraturas dos ossos longos são quase sempre associados a danos extensos aos tecidos moles. Nas Ratitas o osso fêmur é bastante exigido para 
a movimentação do animal, sendo comum ocorrência fraturas (Dolensek \& Bruning, 1986). A redução da fratura pode ser tentada, mas devido ao estresse físico do animal, torna a recuperação improvável (Dolensek \& Bruning, 1986). Isto aconteceu com os dois filhotes fraturados que morreram.

Os valores obtidos de cálcio no osso e de fósforo no osso e no músculo são apresentados na Tabela 8 . Observou-se que, na maioria dos casos, o valor de fósforo no osso foi maior que o de cálcio e possivelmente estes valores estejam relacionados com a falta de calcificação óssea. Os animais 16 e 17 (com 31 dias de idade), teriam uma melhor calcificação e pode-se observar que os valores de cálcio no osso dos mesmos são maiores. Os valores de cálcio e fósforo observados nos avestruzes de 4 a 8 semanas de idade, $22,12 \%$ e $9,12 \%$ respectivamente, (Bezuidenhout et al., 1994), foram maiores aos observados neste trabalho. Essa diferença de valores, possivelmente, esteja relacionada ao fato que a estrutura óssea do avestruz, nessa idade, suporta um peso maior comparado com o peso dos filhotes de ema aos 30 dias que não apresentam a matriz óssea inteiramente calcificada.

Os valores obtidos de selênio nos figados dos filhotes, são apresentados na Tabela 9, observando-se que houve uma grande variação nos resultados obtidos na determinação de selênio no fígado. Esses resultados, podem ser explicados, através do exame histopatológico realizado no órgão, demostrando, que os animais que apresentaram uma menor quantidade de selênio, estavam com processo degenerativo, mais acentuado, no fígado. $E$ aqueles animais que apresentaram um valor maior, encontravamse em processo inicial de degeneração do órgão, sendo que um dos animais que apresentou maior quantidade de selênio no fígado ( $104,6211 \mathrm{ppb})$, foi aquele que teve seu óbito em decorrência a uma fratura, sem ter seu fígado afetado. O valor obtido por Rae (1992) de selênio no fígado, numa ema de 6 meses de idade, foi maior de $176 \mathrm{ppb}$. 
Tabela 8: Valores de cálcio no osso, de fósforo no osso e no músculo nos filhotes de ema, no período pré-experimental, com ração contendo cálcio (máx) $1,50 \%$, fósforo $(\min ) 0,50 \%$.

\begin{tabular}{|c|c|c|c|c|}
\hline NUMERO & SEXO* & $\begin{array}{c}\text { CÁLCIO\% } \\
\text { (osso) }\end{array}$ & $\begin{array}{c}\text { FÓSFORO\% } \\
\text { (osso) }\end{array}$ & $\begin{array}{c}\text { FÓSFORO\% } \\
\text { (músculo) }\end{array}$ \\
\hline $\bar{~} 1$ & 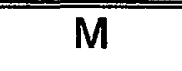 & 6,08 & 7,05 & 0,68 \\
\hline 2 & $\bar{F}$ & 7,45 & 8,27 & 0,37 \\
\hline 3 & $F$ & 5,94 & 9,07 & 0,74 \\
\hline 4 & $M$ & 6,74 & 9,21 & 0,41 \\
\hline 5 & $M$ & 9,82 & 9,35 & 0,63 \\
\hline 6 & $M$ & 5,75 & 8,18 & 0,63 \\
\hline 7 & $F$ & 7,01 & 8,53 & 0,67 \\
\hline 8 & $M$ & 6,51 & 8,92 & 0,63 \\
\hline 9 & $F$ & 8,90 & 9,76 & 0,56 \\
\hline 10 & $\bar{M}$ & 7,34 & 8,34 & 0,75 \\
\hline 11 & $\bar{M}$ & 9,54 & 9,99 & 0,37 \\
\hline 12 & $F$ & 9,5 & 8,86 & 0,85 \\
\hline 13 & $F$ & 6,83 & 8,52 & 0,67 \\
\hline 14 & $F$ & 9,64 & 9,76 & 0,53 \\
\hline 15 & $M$ & 7,17 & 8,50 & 0,73 \\
\hline 16 & $M$ & 13,05 & 10,60 & 0,59 \\
\hline 17 & $\bar{F}$ & 11,89 & 10,44 & 0,73 \\
\hline 18 & $M$ & 8,04 & 8,44 & 0,65 \\
\hline
\end{tabular}

* M (macho); F (fêmea) 
Tabela 9: Valores de selênio no fígado nos filhotes de ema, no período préexperimental.

\begin{tabular}{|c|c||}
\hline $\begin{array}{c}\text { Número } \\
\text { do animal }\end{array}$ & $\begin{array}{c}\text { Valor do selênio no figado } \\
(\mathrm{ppb})\end{array}$ \\
\hline 1 & 65,221 \\
\hline 2 & 54,97 \\
\hline 3 & 50,16 \\
\hline 4 & 40,56 \\
\hline 5 & 46,89 \\
\hline 6 & 50,38 \\
\hline 7 & 68,39 \\
\hline 8 & 70,68 \\
\hline 9 & 105,59 \\
\hline 10 & 107,99 \\
\hline 11 & 65,34 \\
\hline 12 & 93,92 \\
\hline 13 & 85,08 \\
\hline 14 & 104,62 \\
\hline 15 & 81,48 \\
\hline
\end{tabular}




\subsection{Medições do deslocamento das emas.}

As medições feita para avaliar o exercício diário nos filhotes em cativeiro, permitiu observar as tendências de comportamento individual.

Foram obtidas as porcentagens, como medidas descritivas para cada pauta comportamental, observando que a maior parte do tempo as emas se encontravam caminhando (44,29\%) e bicando o chão $(33,70 \%)$, comportamento exploratório. Isso se explica devido a que as emas na natureza andam ininterruptamente (Sick, 1984).

Degen et al. (1989) também observou em cativeiro que o $61,5( \pm 12,5)$ $\%$ do dia, os filhotes de avestruz se encontravam caminhando.

O tempo que as emas permaneceram paradas (limpando suas penas e areando-se), comendo do comedouro, bebendo do bebedouro e correndo paralelo aos arames divisores dos piquetes, foi menor, e não foram observados animais brigando ou dormindo durante o dia.

As emas diariamente entre a 19:00 e 20:00 horas foram levadas nas gaiolas dos piquetes para dormir. Esta aves, quando livres na natureza, ao escurecer procuram um lugar seco, onde haja capões de mato e cerrados, e ali se deitam para dormir (Olalla \& Magalhães, 1956). Foi observado que as emas dormem juntas com o pescoço esticado horizontalmente no chão ou dobrado para as costas, semelhante a posição observada por Sick (1984) e Raikow (1968) e também que os filhotes começavam "assobiar", em algumas ocasiões o faziam juntos e outras vezes somente alguns deles. Este comportamento que no início do experimento durava 20 minutos foi diminuindo até 5 minutos aproximadamente. Durante a noite, na natureza, o macho cobre os filhotes entre seu corpo e suas penas (Daciuk, 1979). O "choro" dos filhotes possivelmente estivesse demostrando a falta de proteção. 
As diferentes tendências das pautas comportamentais, com as porcentagens, dos filhotes de ema, podem ser observadas na Figura 3.

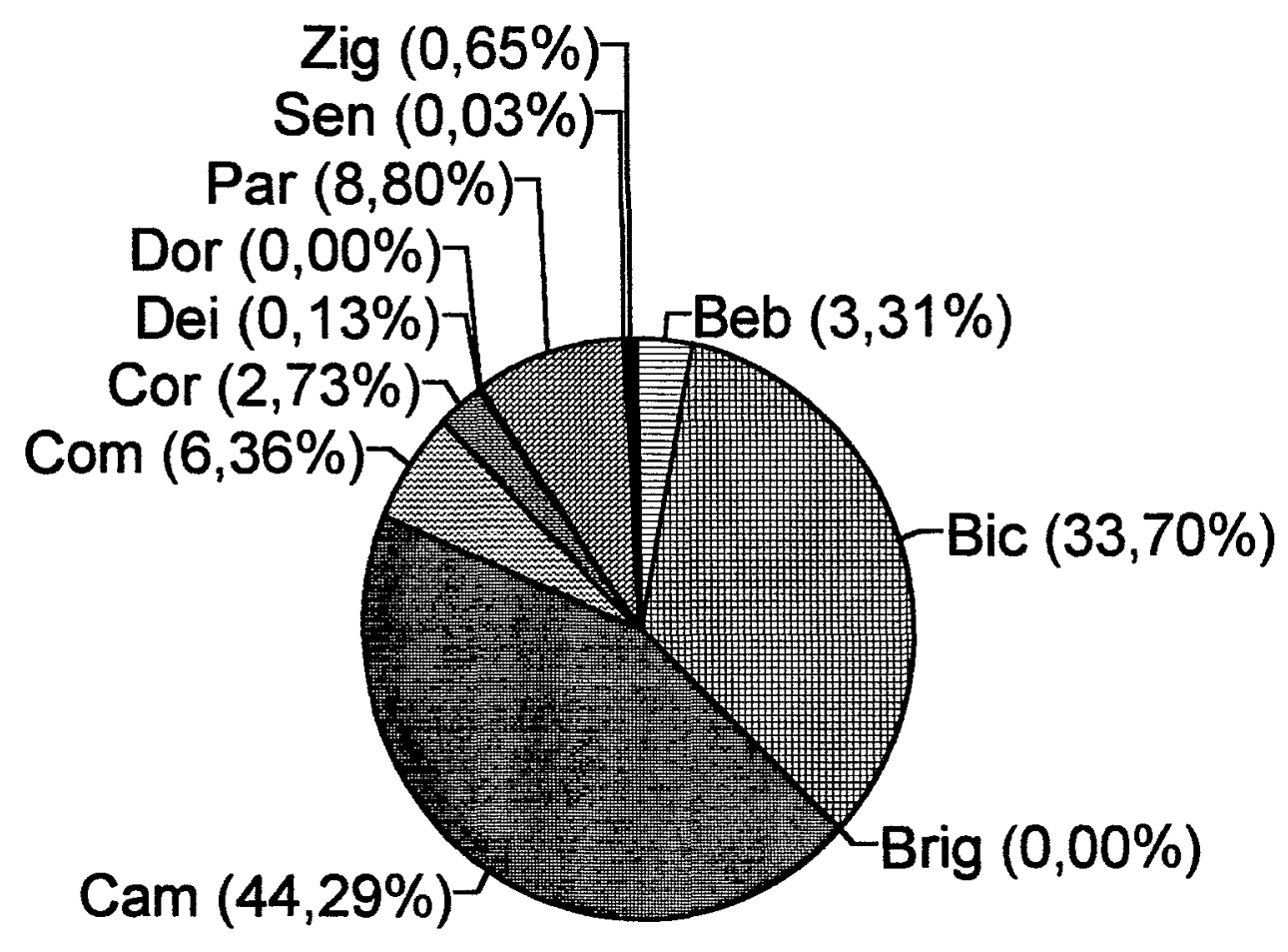

Figura 3: Diferentes tendências das pautas comportamentais diárias dos filhotes de ema, (beb:bebendo; bic:bicando; bri:brigando; cam:caminhando; com:comendo; cor:correndo; Dei:deitado; Dor:domindo; par:parado; sen:sentado; zig:ziguezague). 


\subsection{Efeito das dietas nos parâmetros avaliados}

As medições feitas semanalmente para os parâmetros avaliados, indicaram, valores médios diferentes, estatísticamente $(P<0,0001)$ para os tratamentos, sendo que no tratamento 2 foram maiores que no tratamento 1. Na Tabela 10 são apresentadas os valores médios dos parâmetros estimados semanalmente, para cada um dos tratamentos, com os desvios padrões e os intervalos de confiança (IC) ao nível de $95 \%$ de probabilidade.

Tabela 10 : Análise descritiva dos valores médios, dos parâmetros estimados, semanalmente, peso, consumo, comprimentos do bico, tibiotarso e metatarso, para os tratamentos.

\begin{tabular}{|c|c|c|c|c|c|c|}
\hline \multirow[b]{2}{*}{ variável } & \multicolumn{3}{|c|}{ Tratamento 1} & \multicolumn{3}{|c|}{ Tratamento 2} \\
\hline & $\begin{array}{c}\text { media } \pm \\
\text { desvio } \\
\text { padrão }\end{array}$ & inf. & sup. & $\begin{array}{c}\text { Media } \pm \\
\text { desvio } \\
\text { padrão }\end{array}$ & inf. & sup. \\
\hline peso (g) & $1,459 \pm 644$ & 1,272 & 1,647 & $2,213 \pm 828$ & 2,007 & 2,418 \\
\hline consumo (g) & $576 \pm 275$ & 496 & 656 & $790 \pm 354$ & 703 & 878 \\
\hline $\begin{array}{l}\text { compr. do bico } \\
\text { (cm) }\end{array}$ & $6,37 \pm 0,60$ & 6,58 & 6,88 & $7,34 \pm 0,48$ & 7,18 & 7,50 \\
\hline $\begin{array}{l}\text { compr. do } \\
\text { tibiatarso (cm) }\end{array}$ & $16,93 \pm 3,17$ & 16,1 & 17,7 & $20,01 \pm 2,84$ & 19,1 & 20,9 \\
\hline $\begin{array}{l}\text { compr. do } \\
\text { metatarso }(\mathrm{cm})\end{array}$ & $13,71 \pm 2,41$ & 13,1 & 14,4 & $16,07 \pm 2,37$ & 15,4 & 16,8 \\
\hline
\end{tabular}


Para a variável consumo diário, os valores médios e desvios padrões foram, respectivamente, para o tratamento 1 de $96,31 \pm 36,47 \mathrm{~g}$. e para o tratamento 2 de $112,337 \pm 48,34 \mathrm{~g}$.

Para estudar o comportamento multidimensional do crescimento dos filhotes os dados referentes aos comprimentos do bico, do tibiotarso e do metatarso, foram submetidas a análise de correlação, mostrando os valores estimados para os coeficientes de correlação, apresentados na Tabela 11 e 12 para cada um dos tratamentos. Pode-se observar que as variáveis peso, comprimento do bico, tibiotarso e metatarso estão correlacionadas, o seja estos parâmetros estão altamente associados.

Como pode-se observar, em ambas Tabelas, ha alta correlação entre peso e consumo, peso e tibiotarso, peso e metatarso, tibiotarso e metatarso. Entretanto ha necessidade de ampliar o número amostral.

Tabela 11: Coeficientes de correlação entre as variáveis para o Tratamento 1.

\begin{tabular}{|l|c|c|c|c|c|}
\cline { 2 - 6 } \multicolumn{1}{l|}{} & PESO & CONSUMO & BICO & $\begin{array}{c}\text { TIBIO } \\
\text { TARSO }\end{array}$ & $\begin{array}{c}\text { META } \\
\text { TARSO }\end{array}$ \\
\hline PESO & 1 & 0,734 & 0,822 & 0,927 & 0,916 \\
\hline \hline CONSUMO & 0,734 & 1 & 0,607 & 0,642 & 0,624 \\
\hline BICO & 0,822 & 0,607 & 1 & 0,844 & 0,832 \\
\hline TIBIOTARSO & 0,927 & 0,641 & 0,844 & 1 & 0,962 \\
\hline METATARSO & 0,914 & 0,623 & 0,832 & 0,962 & 1 \\
\hline
\end{tabular}


Tabela 12: Coeficientes de correlação entre as variaveis para o Tratamento 2.

\begin{tabular}{|l|l|l|l||l||l||}
\cline { 2 - 6 } \multicolumn{1}{c|}{} & PESO & CONSUMO & BICO & \multicolumn{1}{|c|}{$\begin{array}{c}\text { TIBIO } \\
\text { TARSO }\end{array}$} & $\begin{array}{c}\text { META } \\
\text { TARSO }\end{array}$ \\
\hline PESO & 1 & 0,905 & 0,808 & 0,949 & 0,965 \\
\hline CONSUMO & 0,905 & 1 & 0,638 & 0,838 & 0,858 \\
\hline BICO & 0,809 & 0,638 & 1 & 0,851 & 0,805 \\
\hline \hline TIBIOTARSO & 0,949 & 0,839 & 0,851 & 1 & 0,946 \\
\hline METATARSO & 0,966 & 0,859 & 0,805 & 0,946 & 1 \\
\hline
\end{tabular}

Foi efetuada a análise de regressāo das variáveis, ao longo do período experimental. Foram corrigidos os valores para as variáveis peso, consumo, tibia, e metatarso em relação ao peso inicial ( ex: peso no tempo í peso inicial $=$ peso corrigido). Pelas Figuras 4,5 , e 6 observa-se, que a taxa de aumento de peso em função do consumo, o comprimento do tibiotarso e o comprimento do metatarso, foram maiores no tratamento 2. $\mathrm{Na}$ Figura 7 observa-se que os ossos tibio-tarso e 0 metatarso cresceram proporcionalmente em comprimento.

Essas informações indicam que as características morfologicas medidas ( comprimentos do bico, tibiotarso e metatarso) poderão ser utilizadas na seleção indireta.

Quando foi considerada a variável ganho de peso semanal, observouse que os desvios padrões eram muito grandes. Decidiu-se estudar a variável "ganho de peso ao final do experimento", fazendo a diferença entre a última e a primeira pesagens. Assim, para o tratamento 1 se obteve uma média de 1,455 $\pm 459,35$, e para o tratamento 2 se obteve uma média de $2,192 \pm 397,96$. 


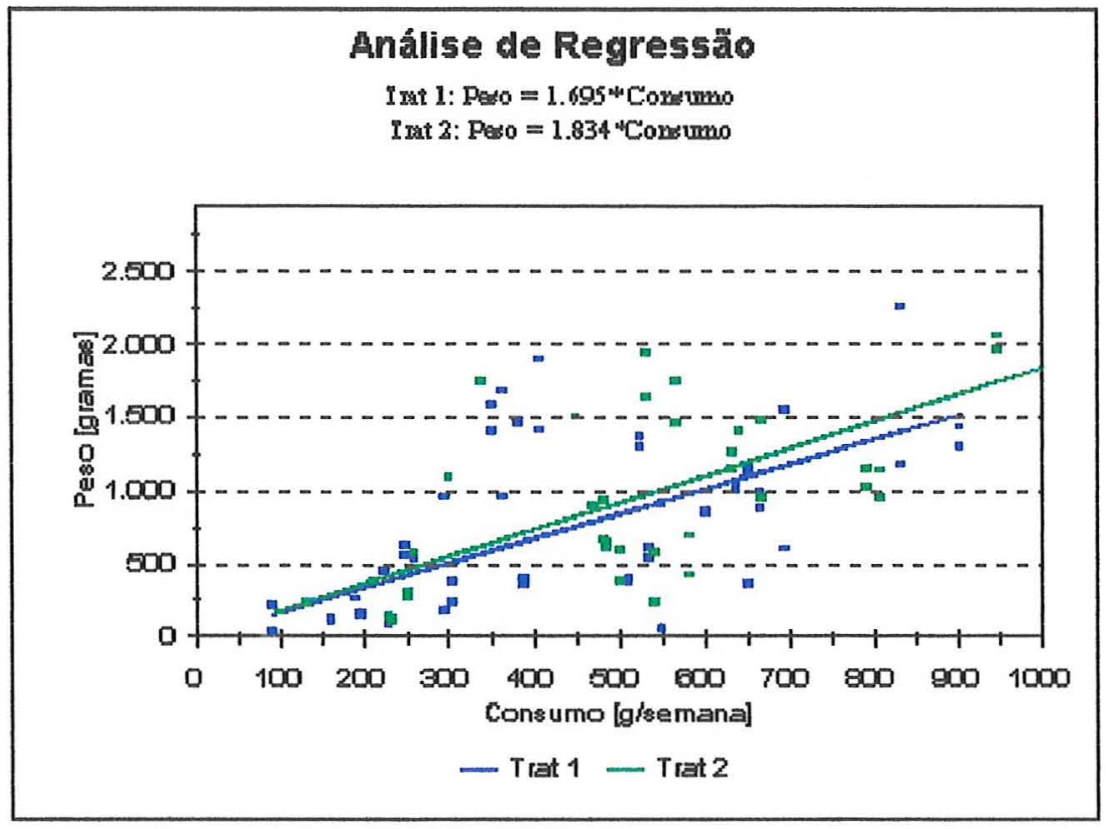

Figura 4: Gráfico de regressão linear do consumo semanal.

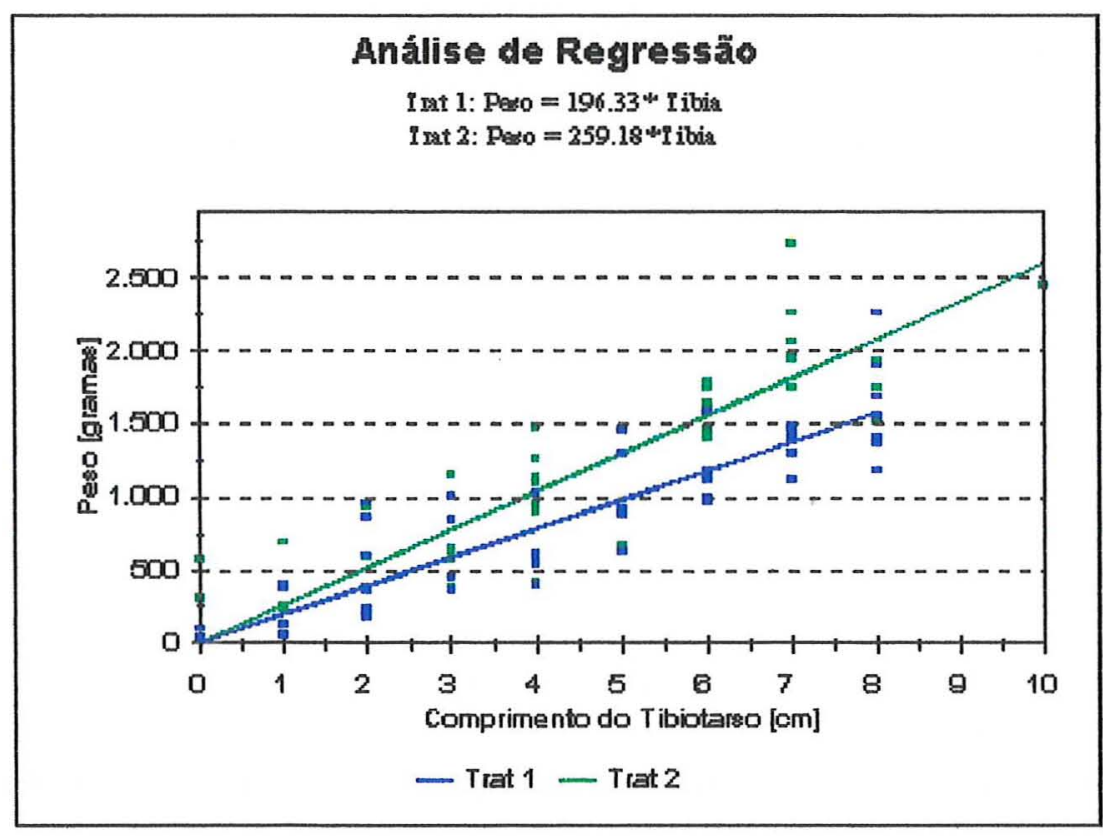

Figura 5: Gráfico de regressão linear do crescimento do tibiotarso 


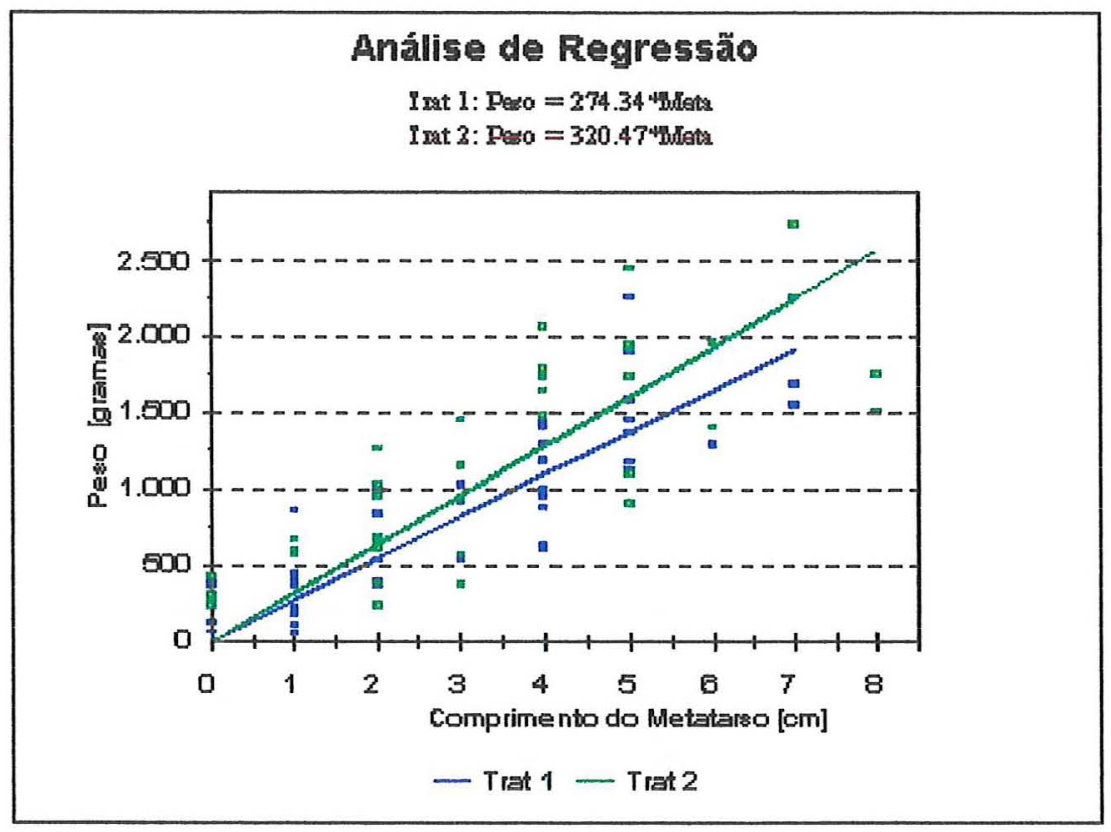

Figura 6: Gráfico de regressão linear do crescimento do metatarso.

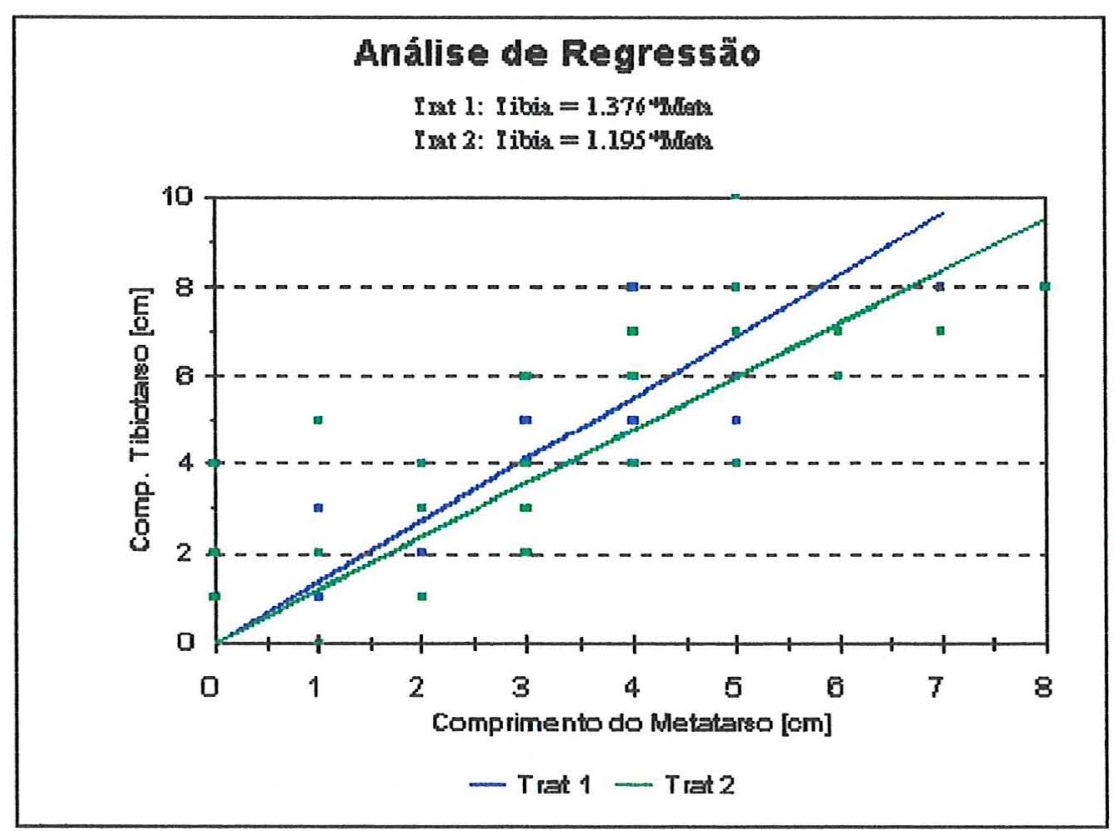

Figura 7: Gráfico de regressão linear, do crescimento proporcional dos osso tibiotarso e metatarso. 
A variável ganho de peso, apresentou um comportamento melhor que a primeira, permitindo realizar uma comparação das médias de tratamentos, (Figura 8) pelo teste de "T", obtendo-se que a media do tratamento 1 foi significativamente menor que 0 do tratamento $2(P=0,01)$. Um tamanho de amostra maior, incrementaria a contabilidade do teste.

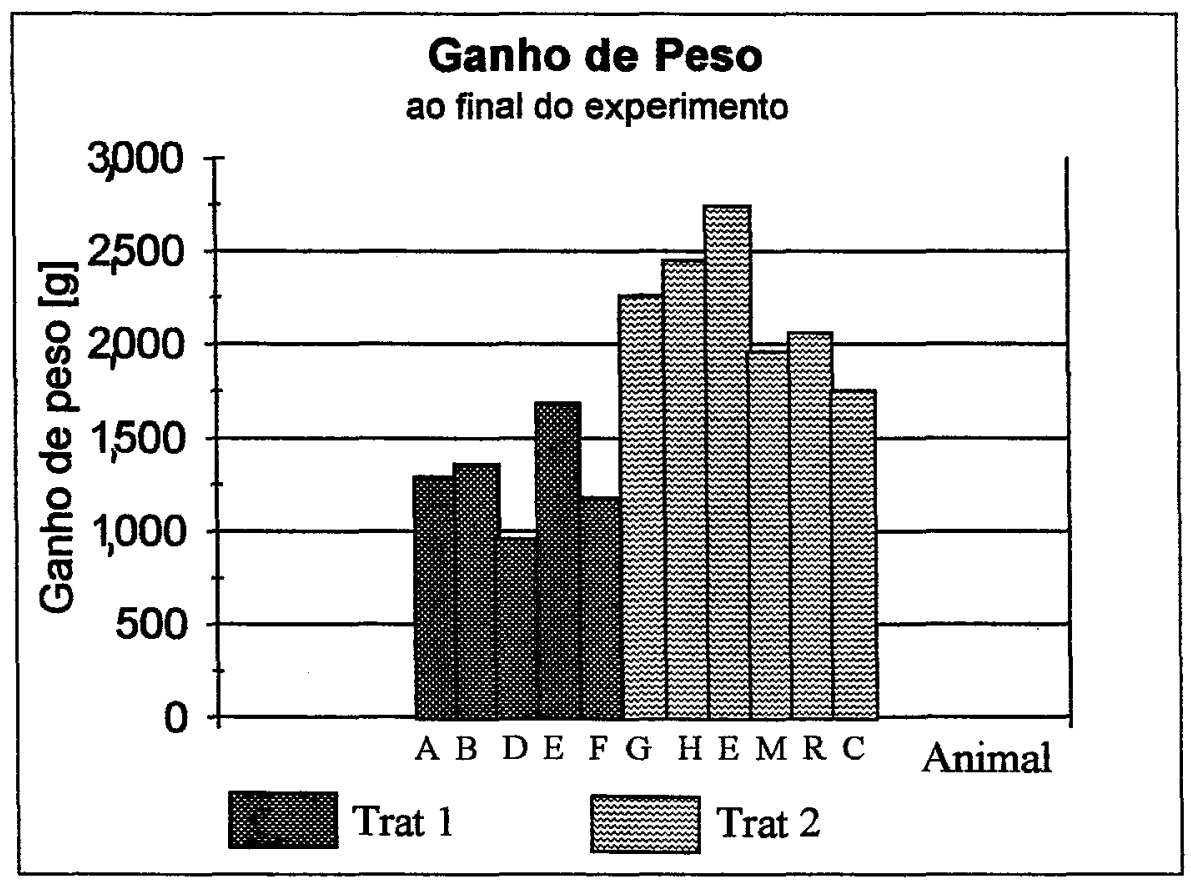

Figura 8: Gráfico descritivo da variável ganho de peso semanal, em ambos tratamentos.

Para verificar hipótese de igualdade dos tratamentos foi usado um teste não paramétrico (Teste de Wilcoxon). Foram observadas diferenças 
significativas entre ambos tratamentos $(P<0,0001)$ para as variáveis estudados. No tratamento 2 se obteve os melhores pesos e os melhores valores nos parâmetros de crescimento. Os filhotes não apresentaram encurvamento nas pernas em nenhum dos tratamentos testados. No Anexo A, programas, é apresentado o programa, do S.A.S, utilizados para este trabalho. 


\section{CONCLUSÃo}

Nas condições em que foi realizado o presente trabalho e para a população estudada, pode-se concluir que:

$\rightarrow$ A dieta com $1,4 \%$ de cálcio e relação cálcio:fósforo $2: 1$, mostrou-se estatisticamente superior à $0,7 \%$ de cálcio e relação $1: 1$, quanto aos melhores pesos e parâmetros de crescimento, em filhotes de 30 a 90 dias de idade.

$\rightarrow$ As radiografias $t$ evidenciaram a mineralização óssea dos filhotes submetidos as dietas testadas.

$\rightarrow \quad$ Verificou-se uma tendência para valores de Hematócritos maiores nas fêmeas que nos machos, em ambos tratamentos, embora as diferenças não tenham sido estatisticamente significativas, tanto para niveis de Hemoglobina como de Hematócrito.

$\rightarrow \quad$ Em ambas dietas não foram observados casos de encurvamentos de pernas nos filhotes de ema na fase de crescimento, mantidos numa área de $100 \mathrm{~m}^{2}$, com substrato de terra e capim, e onde os filhotes consigam deslocarse normalmente. 


\section{REFERÊNCIAS BIBLIOGRÁFICAS}

ANDRADE, M.A. A vida das aves: introdução à biologia e conservação. Belo Horizonte: Fundação Acangaú, 1993. 160p.

ANDRIGUETTO, J.M.; PERLY, L.; MINARDI, I.; et al. Nutrição animal. São Paulo: Nobel, 1988. 395p.

ANGEL, R. Research update: age changes in digestibility of nutrients in ostrich and nutrient profiles of status of the hen and chick. In: ANNUAL CONFERENCE OF THE ASSOCIATION OF AVIAN VETERINARIANS, 1993. Proceedings. Orlando: AAV, p. 275-281.

ANON. DNA sexing. Canadian Ostrich, v.4, n.2, p.20, Feb.1995. Resumo em Ladd, k. (comp.). Ratites bibliographys. on CD-ROM.

ALMAZAN, M.D.; RIAMBAU, M.; MARTINEZ, M.; VILLACAMPA, V.; BACHS, E. Natura, enciclopedia de los animales. Barcelona: Orbis, 1986. v. 62, parte 1/2, p.18-27: El avestruz y especies emparentadas.

BEZUIDENHOUT, A.; BURGER, W.P. The incidence of tibiotarsal rotation in the ostrich (Struthio camelus). Journal of the South African Veterinary Association, v.64, n.4, p.150-161, Dec. 1993.

BEZUIDENHOUT, A.; BURGER, W.P.; REYERS, F.; SOLEY, T. Serum and bone mineral status of ostriches with tibiotarsal rotation. Onderstepoot Journal of Veterinary Research, v. 61, p.203-206, July 1994. 
BRITO, P. Observações sobre o comportamento e a reprodução da ema, Rhea americana americana (L) em cativeiro. Boletim do Museu Nacional do Rio de Janeiro. Zool Ser, v. 89, p. 1-6, 1949.

BRUNING, D. Raising Rheas in captivity. Gazette, v.20, n. 10/11, p.7-12, 1971.

BRUNING, D. Breeding and rearing rheas in captivity. International Zoo Yearbook, v.13, p. 163-174, 1973.

BRUNING, D. Social struture and reproductive behavior in the greater rhea. Living Bird, v. 13, p. 251-294, 1974.

CANEVARI, M.; CANEVARI, P.; CARRIZO, G.; HARRIS, G.; RODRIGUEZ MATO, J.; STRANECK, R. Nueva guia de las aves Argentinas. Buenos Aires: Fundación Acindar, 1991. t.1, p. 114-115.

CHAPMAN, H.; BASS, F. Modern concepts for commercial Rhea Prodution. Palm City : Porter Professional Publishers, 1994. 83p.

CHO, P.; BROWN, R.; ANDERSON, M. Comparative gross anatomy of Ratites. Zoo Biology, v.3, p.133-144, 1984.

COIMBRA FILHO, A.; CRUZ ROCHA, N. Aspectos do processo nutricional de animais selvagens em cativeiro. Brasil Florestal, v.4, n.14; p.19-35, 1973. 
CRACRAFT, J. Phylogeny and evolution of the Ratite birds. The Ibis, v.116, n.4, p.494-521, oct. 1974.

DACIUK, J. Notas faunisticas y bioecologicas de Peninsula Valdes y Patagonia. XXXIII. Estudio bioecológico y etológico general del ñandú petiso Patagonico y de los Tianmidos de Peninsula Valdes, Chubut, Argentina (Aves, Rheidae y Tinamidae). Phisis, v.38, n. 95, p. 69-85, dec. 1979.

DANI, S. A ema (Rhea americana): biología, manejo e conservação. Belo Horizonte: Fundação Acangaú, 1993. 136 p. (Coleção Manejo da Vida Silvestre).

DEGEN, A.A.; KAM, M.; ROSENSTRAUCH, A. Time activity budget of ostriches (Struthio camelus) offered concentrate feed and maintained in outdoor pens. Applied Animal Behaviour Science, v.22, n.3/4, p.347-358, 1989.

DOLENSEK, E.; BRUNING, D. Ratites (Struthioniformes, Casuariiformes, Rheiformes, Tinamiformes, and Apterygiformes). In: FOWLER, M. Zoo \& wild animal medicine. Philadelphia: W.B.Saunders, $1986 . \quad$ cap.22, p.276-292.

DRENOWATZ, C. The Ratite encyclopedia Ostrich, Emu, Rhea. Ratite Records. Texas: San Antonio, 1995. 478p.

DURIGAN, G.; GARRIDO, M. Criação da ema (Rhea americana) em cativeiro. Boletim Técnico do Instituto Florestal, v.40A, n.1/2, p.77-87, 1986. 
EL ÑANDÚ. Buenos Aires: Centro Editor de America Latina, $1983.31 \mathrm{p}$. (Fauna Argentina, 10).

FEZLER, D.; BEAL, D. Rubber rhea syndrome and fading chick syndrome in rheas and ostriches. In: The Rhea Report. The official Publication of the North American Rhea Association, 1996. v.3,n.1, p.16-21.

FISKE, C.H.; SUBBAROW, Y. The colorimetric determination of phosphorus. Journal of biological Chemistry, v.66, n.2, p.375-400, 1925.

FLIEG, G.M. Nutritional problems in young Ratites. International Zoo Yearbook, v.3, p.158-163, 1973.

FOWLER, M. Comparative clinical anatomy of Ratites. Journal of Zoo and Wildlife Medicine, v.22, n.2, p.204-227, 1991.

GIANNONI, M.L. Ema \& avestruzes: uma alternativa para o produtor rural. Jaboticabal: FUNEP, 1996. 49p.

GIANNONI, M.L.; SANCHEZ, M.E. As espécies sul americanas do grupo das Ratitas. Atualidades Ornitológicas, v.64, p.4-5, 1995.

GUITTIN, P. Bow leg syndrome in Ratites birds. Avicultural Magazine, v.92, n.2, p.71-79, 1986. 
GUNSKI, R.J. Análise citogenética e algumas considerações biológicas da espécie Rhea americana- Ema (Aves:Rheidae). Jaboticabal, 1992. 129p. Dissertação (Mestrado) - Faculdade de Ciências Agrárias e Veterinárias, Universidade Estadual Paulista "Júlio de Mesquita Filho".

HANDFORD, P.; MARES, M.A. The mating systems of ratites and tinamous: an evolutionary perspective. Biological Journal of the Linnean Society, v.25, p.77-104, 1985.

HERD, R.; DAWSON, T.J. Fiber digestion in the emu, Dromaius novaehollandiae, a large bird with a simple gut and high raes of passage. Physiological-Zoology, v.57, n.1, p.70-84, 1984. Resumo em Ladd, K. (comp.). Ratites bibliography. on CD-ROM.

HOCTOR, P.D. Rhea - and the management of their young. (Separata de MULTI-STATE BIG BIRD CONFERENCE, 1993. p. 1-7)

INSKIPP, T.; BROAD, S.; LUXMOORE, R. (Ed.). Significant trade in Wildlife: review of selected species in CITES Appendix II. S.L. CITES-IUCN Conservation Monitoring Centre, 1988. v.3: Birds, p.1-6: Argentinian Greater Rhea.

JENSEN, J. Husbandry, medical and surgical management of ratites: part I. Proceeding of the American Association of Zoo Veterinarians, p.113$118,1989$. 
JENSEN, J.; JOHNSON, J.H.; WEINER, S.T. Husbandry and medical management of ostriches, emus and rheas. S.L.: Wildlife and Exotic Animal TeleConsultants, 1992. 129p.

JUNCKER, T. Little creek ostrich ranch. (Separata de MULTI-STATE BIG BIRD CONFERENCE, Indianajpoli, 1993. p.1-5.)

KUEHLER, C.; GOOD, J. Artificial incubation of bird eggs at the Zoological Society of San Diego. International Zoo Yearbook, v.29, p.118-136, 1990.

LINT, K.C.; LINT, A.M. Dieta para aves en cautiverio. Buenos Aires: Ballestera, 209p.

LOUVANDINI, H. Perda endógena de fósforo em ovinos suplementados com diferentes níveis do elemento na dieta. São Paulo, 1995. 87p. Tese (Doutorado) - Instituto de Pesquisas Energéticas e Nucleares.

MAGNANI, F.S.; PASCHOAL, F.R. Dispersão de sementes pela ema ( Rhea americana) em condiçōes de cativeiro. In: CONGRESSO BRASILEIRO DE ZOOLOGIA, 17, Londrina, 1990. Londrina: SBZ, 1990. p.172.

MARTIN, P.; BATESSON, P. Measuring behaviour. Washington: FRS, 1986, $200 p$.

MCLELLAND, J. Anatomy of the avian cecum. The Journal of experimental Zoology, v.3, p.2-9, 1989. Supplement. 
MOOJEN, J.; CANDIDO, J. C. de ;SOUZA, H. L. de Observações sobre o conteúdo gástrico das aves brasileiras. Memórias do Instituto Oswaldo Cruz, v. 36, n.3, p.405-406, 1941.

MUIRHEAD, D. Ratite gastrointestinal physiology, nutrition principles explored. Feedstuffs, v.67, n.41, p. 12, 31, 1995.

MUÑIZ, F. Escritos científicos, 1916 . pt.3, p83-218: La cultura Argentina.

OKOTIE-EBOH, G.; BAILEY C.A.; HICKS, K.D.; KUBENA, L.F. Reference serum biochemical values for emus and ostriches. American Journal Veterinanian Research, v. 53, n.10, p.1765-1768, 1992.

OLALLA, A.M.; COUTO DE MAGALHÃES, A. Vida, regime, costumes caça, utilidade e preparação taxidérmica (embalsamação) das aves e mamíferos do Brasil. 1956. p.11-24: Aves-Fam.Rheidae.Gen.Rhea. (Biblioteca Zoológica, 1).

ONELLI, C. Los avestruces en libertad y en domesticidad. Revista Jardín Zoológico, v.2, n.1, p.150-168, 1905.

RAE, M. Degenerative myopathy in Ratites. Proceeding Association of Avian Veterinarians, p.328-335, 1992.

RAIKOW, R.J. Maintenance behavior of the common rhea. The WilsonBulletin, v.8, n. 3, p.312-319, 1968. 
RAIKOW, R.J. Sexual and agonistic behavior of the common rhea. The Wilson-Bulletin, v.81, p.196-206, 1969.

REECE , R.L.; BUTLER, R. Some observation on the development of the long bones of ratite birds. Australian Veterinary Journal, v. 61, n.12, p.403$405,1984$.

RUSCHI, A. Aves do Brasil. Rio de Janeiro: Ed. Rios, 1979,335p.

SANFORD, E.S.; REHMTULLA, A.J. Impactation in a Rhea. Canadian Veterinary Journal, v.34, p.184-185, 1993.

SANTOS, E. Da ema ao beija-flor. 5. ed. Rio de Janeiro: Villa Rica, 1990.

SARACURA, V. Crescimento inicial e entortamento de pernas de ema (Rhea americana) em cativeiro, sob três níveis de energía na ração. Piracicaba, 1993. 108p. Dissertação (Mestrado) - Escola Superior de Agricultura "Luiz de Queiroz" Universidade de São Paulo.

SCHEIDELER, S.E.; ANGEL, R. Nutrition update: feeding big birds. Large Animal Veterinarians v.49, n.2, p. 28-30, 1994.

SHERWOOD, A.R.; PARSONS, T. Anatomia comparada dos vertebrados. São Paulo: Atheneu, $1985 . \quad 559 p$. 
SHIVAPRASAD, H.L. Neonatal mortality in ostrich: an overview of possible causes. Proceedings of the Annual Conference of the Association of Avian Veterinarian, p. 282-293, 1993. Resumo em Ladd, K. (comp.). Ratites Bibliographys. On CD-Rom.

SHWALUK, T.W.; FINLEY, D.A. Proventricular-ventricular impaction in an ostrich chick. Canadian Veterinary Journal, v. 36, n. 2, p.108-109, 1995.

SICK, H. Ornitología brasileira: uma introdução. 3. ed. Brasilia: Universidade de Brasilia, 1984. 827p.

SIGLER, D.H. Basic nutrients for Ratites. Separada de: MULTI-STATE BIG BIRD CONFERENCE, 1994, p.1-5.

SILVA, L. da J. M. Patologia do frango de corte na década de 80 . In: SEMINÁRIO TÉCNICO SOBRE MANEJO, NUTRIÇÃO E DOENÇAS DAS AVES, 2, São Paulo: 1984. p.13-28.

SMITH, C.A. Ostrich chick survival presents challenge. Journal of the American Veterinary Medical Association, v.203, n.5, p.637-643, 1993.

STATISTICAL ANALYSIS SYSTEM. SAS System for linear models. Cary: SAS Institute, $1986.211 p$.

STURKIE, P. Fisiologia aviar. Zaragoza:Acribia, 1968. 607p. 
SWART, D.; MACKIER, R.I.; HAYES, J.P. Influence of live mass, rate of passage and site of digestios on energy-metabilism and fiber digestion in the ostrich (Struthio camelus, var domesticus). South African Journal of Animal Science, v.23, n. 5/6, p.119-126, 1993.

SWENON, M.J. Dukes fisiologia dos animais domésticos. 10. ed. Rio de Janeiro: Koogan, 1988. 799p.

TARDIN, A.C. Visão nutricional dos problemas locomotores em frango de corte. In: SEMANA AVÍCOLA 95; CONFÊRENCIA APINCO 1995 DE CIÊNCIA E TECNOLOGIA AVÍCOLA, Curitiba, 1995. Campinas: Apinco, 1995, cap.8, p.71-83.

WADE, J.R. Ratites pediatric medicine and surgery. Proceedings of the Association Avian Veterinarians, p. 340-353, 1992.

WALLACH, J.D. Nutritional diseases of exotic animals. Journal of the American Veterinary Association, v.157, n.5, p.583-599, 1970.

WALLACH, J.D.; BOEVER, W.J. Diseases of exotic animals: medical and surgical management. Rio de Janeiro: W.B. Saunders, 1983.

$1159 p$.

WALLER, T. Breve reseña del comercio Argentino del Ñandú (Rhea americana albescens, Arribalzaga y Holmberg, 1878) pasado, presente y futuro. Alerta, v.2, n.1, p. 8-10, 1991.

WEICHERT, CH.K. Elementos de anatomia de los cordados. 2.ed. Madrid: Del Castillo, 1965. 509p. 
WETMORE, A. Observations on the birds of Argentina, Paraguay, Uruguay and Chile. Bulletin of the U.S. National Museum, v.133, p.23-27, 1926.

WILLIS, H.H. A simple levetation method for the detection of hook worma ova. Medi. Journal Australia, v.8, p.375-376, 1927. 
ANEXO A

- FIGURAS e PROGRAMA- 


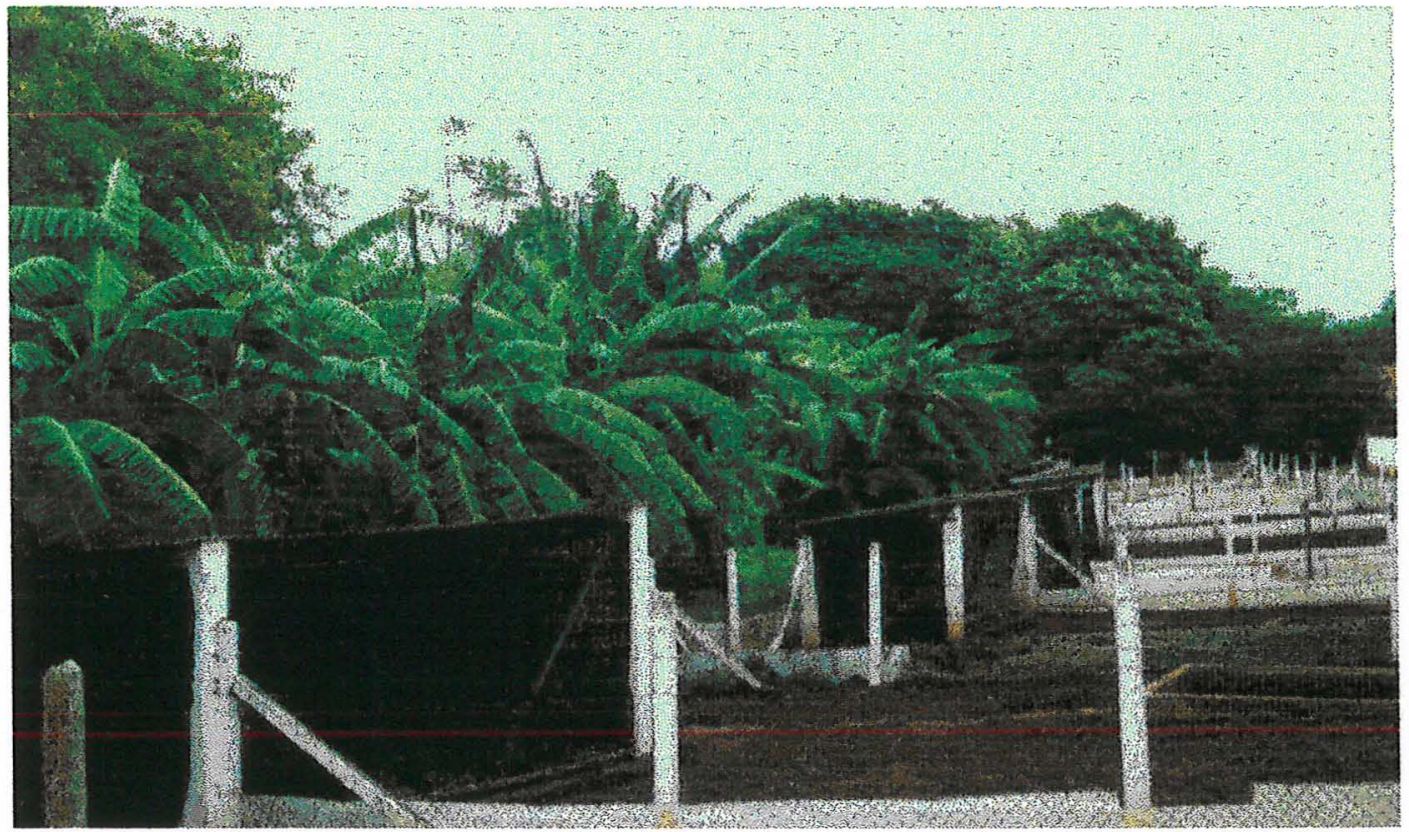

Figura 1:Piquetes experimentais, com as telas pretas de proteção, da área coberta.

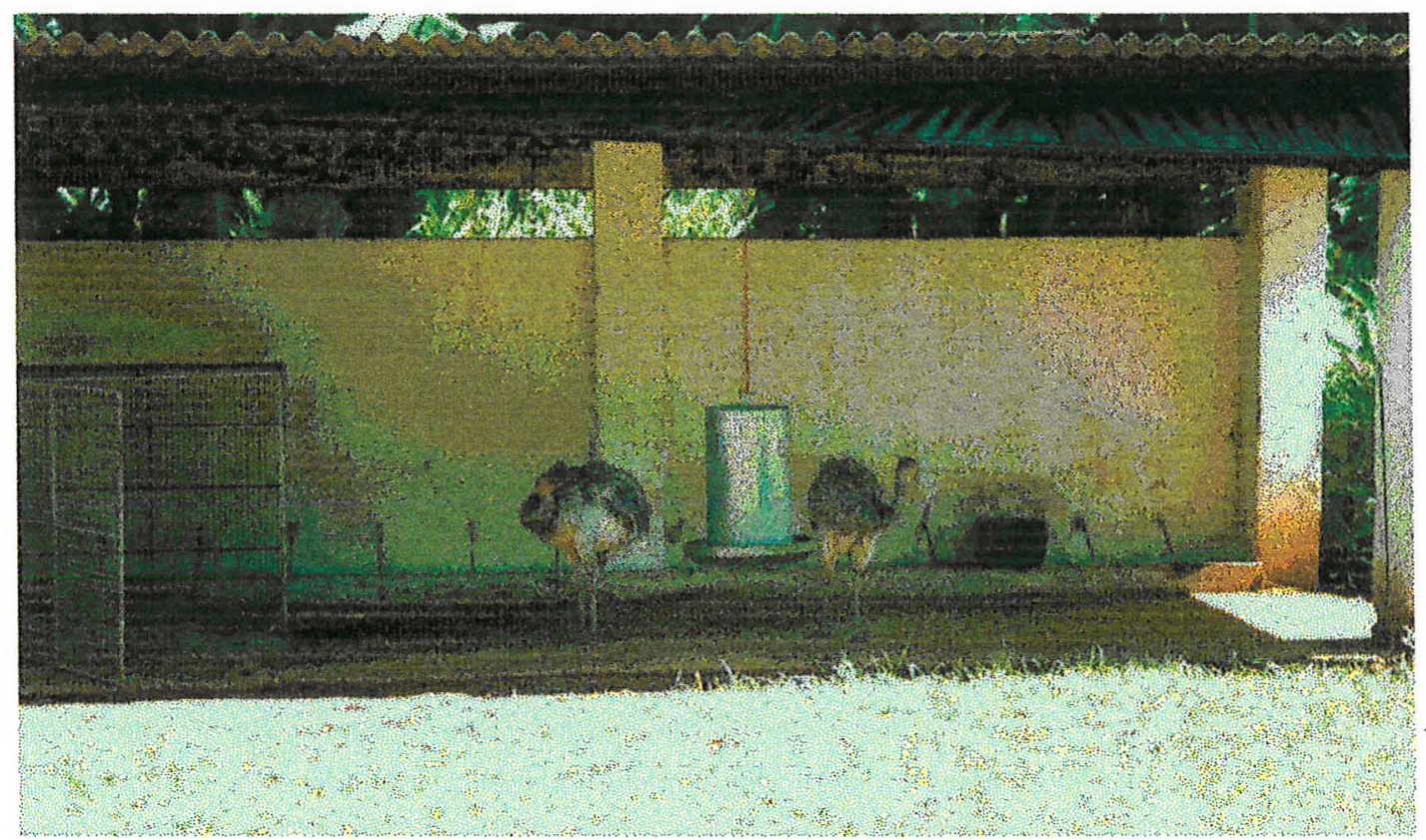

Figura 2 : Área coberta de $10.21 \mathrm{~m}^{2}$, com a gaiola para os animais dormirem a noite o comedouro pendurado e o bebedouro. 
PROGRAMA:

data Ema;

input ANI \$ DIA \$ DIET PESO CONS BICO TIBIA META;

cards;

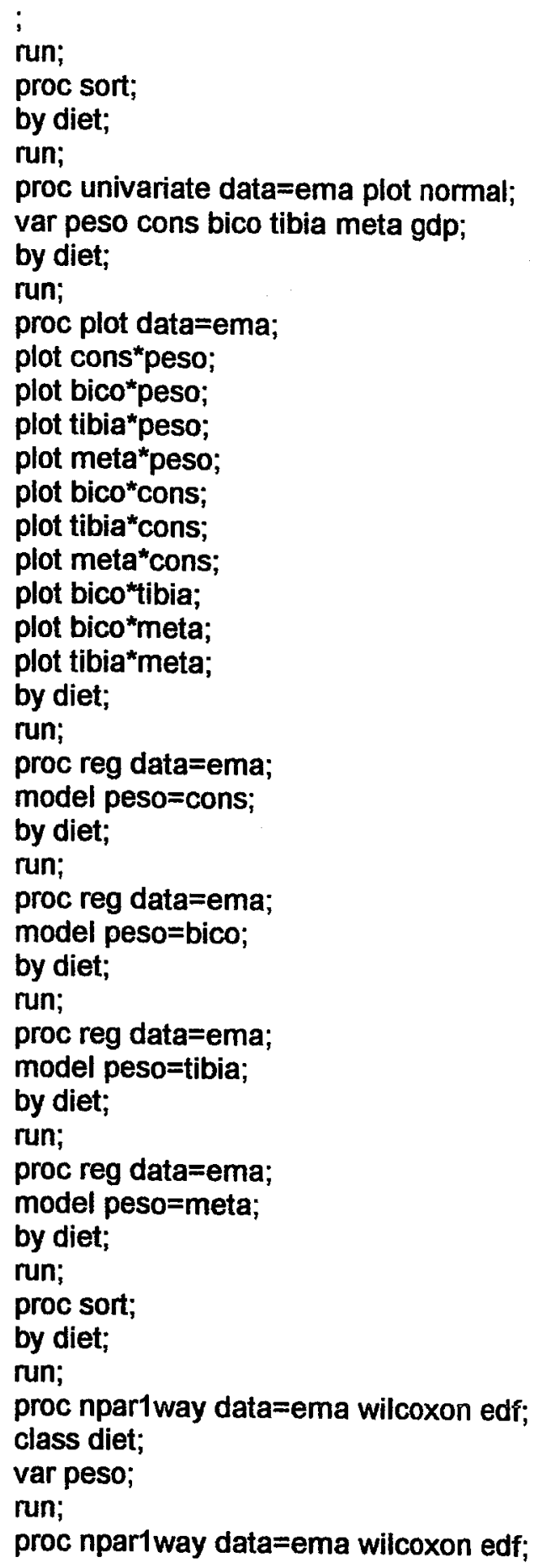

;

run;

proc sort;

by diet;

run;

proc univariate data=ema plot normal;

var peso cons bico tibia meta gdp;

by diet;

run;

proc plot data=ema;

plot cons*peso;

plot bico*peso;

plot tibia*peso;

plot meta*peso;

plot bico*cons;

plot tibia*cons;

plot meta*cons;

plot bico*tibia;

plot bico*meta;

plot tibia*meta;

by diet;

run;

proc reg data=ema;

model peso=cons;

by diet;

run;

proc reg data=ema;

model peso=bico;

by diet;

run;

proc reg data=ema;

model peso=tibia;

by diet;

run;

proc reg data=ema;

model peso=meta;

by diet;

run;

proc sort;

by diet;

run;

proc npar1way data=ema wilcoxon edf; class diet;

var peso;

run;

proc npar1 way data=ema wilcoxon edf; 
class diet;

var cons;

run;

proc npartway data=ema wilcoxon edf;

class diet;

var bico;

run;

proc npar1way data=ema wilcoxon edf; class diet;

var tibia;

run;

proc npariway data=ema wilcoxon edf; class diet;

var meta;

run;

$\square$ 
APÊNDICE 1

- MAPA - 


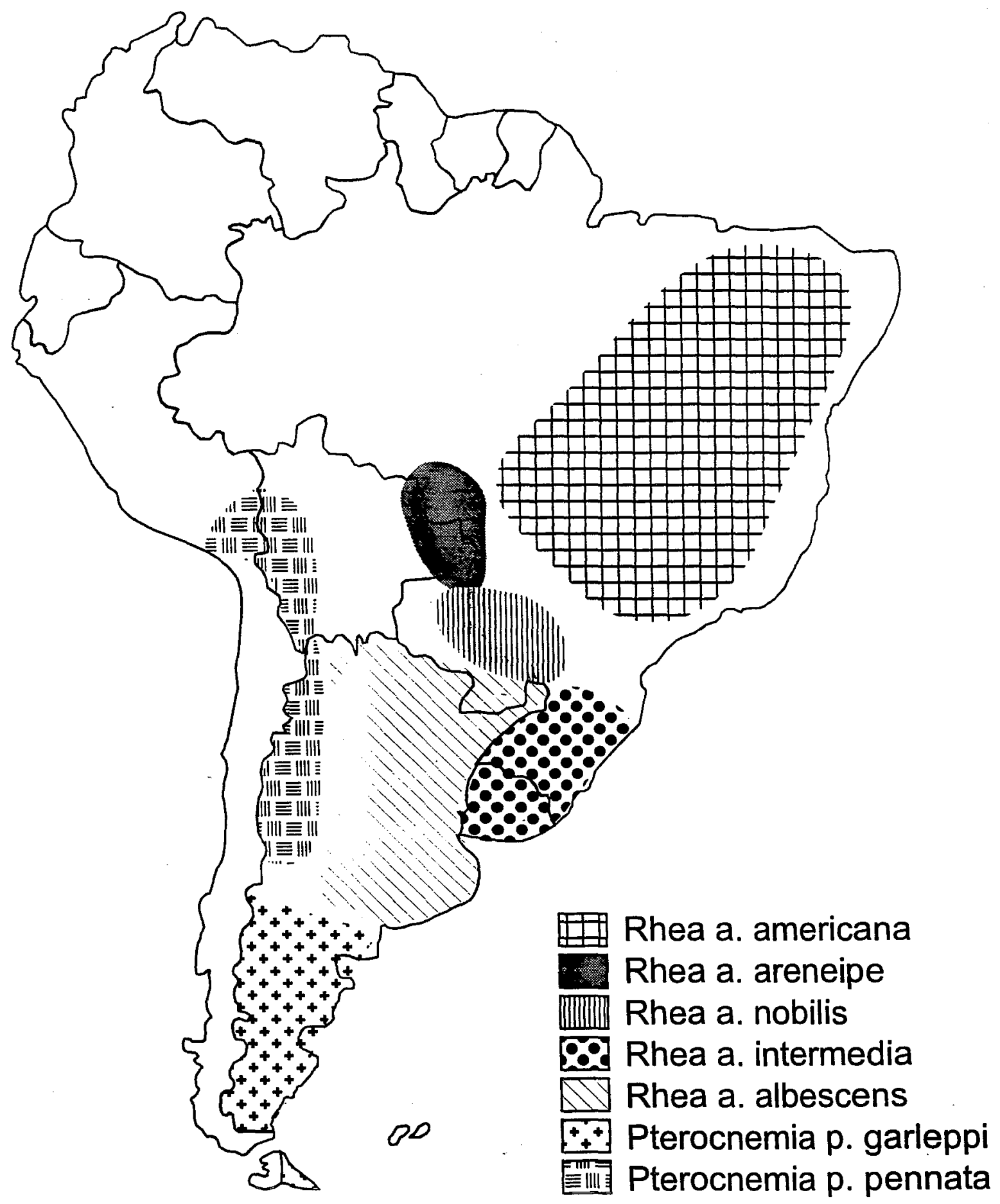

Mapa 1: Distribuição da Familia Rheidae 